\title{
VESTÍGIOS DO CORPO EM UM ROMANCE DE FICÇÃO CIENTÍFICA
}

\section{BODY TRACES IN A SCIENCE FICTION NOVEL}

\author{
EDISON GOMES* \\ ELIZABETH HARKOT-DE-LA-TAILLE*
}

RESUMO: Revendo a relação entre corpo, cultura e linguagem (iniciada em Sémiotique des Passions, 1991), Jacques Fontanille procura estabelecer, na teoria semiótica francesa, um diálogo entre o sensível e o inteligível, a partir de um novo ângulo: assumindo um corpo biopsíquico como importante entidade na construção do sentido, responsável por unir expressão e conteúdo, e presente no texto como vestígio da experiência, transformado em semiótica-objeto, plano de imanência e figura. No livro Corps et Sens (2011), o semioticista entrelaça arcabouços teóricos oriundos das ciências humanas e naturais, com conceitos de ordem semiolinguística, propondo uma abordagem do sentido que relaciona a propriocepção, a enunciação, a figuração, os campos sensoriais, os vestígios materiais e a percepção de fenômenos, buscando uma relação entre corpo, discurso e práticas semióticas. Nesse artigo, pretende-se demonstrar facetas desse tipo de abordagem em relação ao texto literário. 0 romance escolhido, Os androides sonham com ovelhas elétricas? (1968), é um famoso texto de Philip K. Dick, autor norte-americano de ficção científica co-

\footnotetext{
* Doutorando da USP - Universidade de São Paulo. E-mail: digomes2000@uol.com.br .

** Docente da USP - Universidade de São Paulo. E-mail: beth.harkot@usp.br .
} 
nhecido por produzir mundos distópicos e personagens que estão sempre à volta com questões sobre a identidade e os seus corpos.

PALAVRAS-CHAVE: Semiótica do vestígio. Corpo. Philip K. Dick. Ficção científica.

ABSTRACT: Reviewing the relationship among body, culture and language (started in The Semiotics of Passions, 1991), Jacques Fontanille seeks to establish a dialogue between the sensible and the intelligible from a new angle in the French semiotic theory: accepting a biopsychic body as an important entity in the construction of meaning, responsible for uniting expression and meaning, and present in the text as trace of experience, and turned into semiotic object, plane of immanence and content. In the book Corps et Sens (2011), the semiotician interweaves theoretical frameworks built in the human and natural sciences, with semiolinguistic concepts, proposing an approach which relates proprioception, enunciation, figures, sensory fields, body traces and the perception of phenomena, searching for a relationship among body, discourse and semiotic practices. In this article, we intend to demonstrate what this kind of approach can reveal about the literary text. The novel chosen, Do androids dream of electric sheep? (1968), is a famous text by Philip K. Dick, science fiction American author, known mainly for producing dystopic worlds and characters who must always deal with identity issues and their bodies.

KEYWORDS: Semiotics of trace. Body. Philip K. Dick. Science fiction. 


\section{Introdução}

A visão de Jacques Fontanille em relação ao sentido e à sua produção não diverge, mas difere da visão de Greimas, fundador da semiótica francesa clássica. Enquanto para este o sentido só pode emergir do texto (e a experiência do fenômeno não pode ser esquematizada de outra maneira), para aquele, cujo ponto de vista é sociocultural, o sentido possui uma imanência extratextual ${ }^{1}$. Fontanille, em Pratiques Sémiotiques (2008), retorna à questão, cara à Greimas, da "existência semiótica" modalizada, segmentada em planos de análise, e convertida em conteúdos de significação articulados em níveis distintos (elementares, narrativos e discursivos), e adapta a mesma ideia para o percurso gerativo da expressão, pressupondo "uma experiência semiótica" ${ }^{2}$ antes de uma "experiência narrativa". Assim, o sensível fenomenal e sua esquematização semiótica, relacionados à expressão, não podem prescindir de uma hierarquia de semióticas-objeto que constituem uma cultura: os níveis de experiência são "semiotizados" e convertidos em formas da experiência e planos de imanência.

Em Pratiques Sémiotiques, Fontanille (2008, p.34) desenvolve uma hierarquia de níveis de imanência que emerge de tipos de experiência e instâncias formais respectivas (formas da expressão), articuladas a vários graus de pertinência

1 Segundo o semioticista, considerar toda a manifestação semiótica como "texto", pode ser uma visão precipitada, talvez um "abuso metafórico" (discussão apresentada em Pratiques Sémiotiques, 2008, no capítulo: "Immanence et pertinence des pratiques".

2 Fontanille, em Pratiques Sémiotiques (2008, p. 18), observa que a distinção tradicional entre expressão e conteúdo, como tipos de formas, é relacionada a uma distinção mais geral entre experiência e existência, como substâncias. Essa relação, baseada no princípio de um "horizonte ôntico" da significação, revela uma instância da enunciação que se coloca como instância que existe e experimenta o mundo que ela tenta significar. 
que se comunicam e se absorvem: a experiência da figurativização (cujas instâncias formais são signos), a experiência da coerência e da coesão interpretativas (cujas instâncias formais são textos-enunciados, que não devem ser confundidos com a narrativa), a experiência da corporeidade (cujas instâncias formais são objetos), a experiência da prática (cujas instâncias formais são cenas práticas), a experiência da conjuntura (cujas instâncias formais são estratégias), e a experiência do éthos e do comportamento (cujas instâncias formais são as formas de vida).

Assim, o teórico não abandona os conceitos de base da semiótica greimasiana, mas procura alargar o seu escopo. As conversões entre os níveis de pertinência da significação são consideradas não apenas como operações lógicas de natureza especulativa e linguística, mas operações que revelam, em sua base, "um sujeito epistemológico dotado de um corpo, que percebe conteúdos significantes, calcula-os e projeta valores" (FONTANILLE, 2011, p. 5) $)^{3}$. Dentro dessa visão sociocultural sobre a produção da significação, o corpo adquire uma importância primordial (ausente na semiótica francesa clássica), pois conjuga o sensível e o inteligível, e está envolvido nos tipos de experiência acima descritos ${ }^{4}$.

De forma geral, o corpo sensível permeia toda a obra de Fontanille, que sempre retorna à questão da "percepção como lugar não linguístico onde se situa a apreensão da significação" (GREIMAS, 1966, p. 15), tentando demonstrar como o sujeito corporificado estabelece, ao tomar posição no mun-

3 A tradução das passagens do livro Corps et Sens é nossa.

4 Ao falar sobre o corpo na cultura, Fontanille (2011, p. 7) explica: “o corpo é, para esse grupo étnico, uma configuração semiótica (partes, força de ligação e formas de totalidade), podendo ser objeto de uma leitura sensível (tátil, visual, olfativa, etc.) durante as interações sociais, e é também motivação para uma semiotização da vida e do mundo inteiro". 
do, uma fronteira entre o que será da ordem da expressão (o mundo exterior; e também o das práticas) e o que será da ordem do conteúdo (o mundo interior; e também o da cognição), articulando uma função semiótica através da propriocepção (sede de correlações de onde o sentido emerge). 0 semioticista postula que, se existem percepções de presenças materiais e somáticas no texto (lógico/ semânticas), há então, no enunciado, um corpo que é possível teorizar ${ }^{5}$, pois ele existe como vestígio da existência proprioceptiva. A partir das práticas semióticas, pode-se inferir que o enunciador adquire um caráter duplo: é tanto uma forma textual, pois possui uma memória virtual de enunciados que ele atualiza, realiza e potencializa, por meio de uma práxis enunciativa; como é também instância que existe e experimenta, ou seja, habita um corpo espesso e convertido em semiótica-objeto. Assim, o enunciador pode ser tomado como um ente linguageiro e corporificado, que projeta no texto figuras semióticas materiais, tridimensionais, dotadas de morfologia, funcionalidades e formas exteriores identificáveis, e cujos conjuntos são destinados a usos ou práticas mais ou menos especializadas.

Esse novo tipo de abordagem assume uma ambivalência que resulta do duplo estatuto corporal na produção de conjuntos significantes como: (a) substrato da semiose e assunto teórico, uma vez que o corpo participa da substância semiótica e da determinação do actante; (b) figura ou configuração semiótica, manifestação visível nos textos e nas semi-

5 “A expressão somática nos lembra, com razão, que o afeto está ligado primeiramente ao corpo: até mesmo os atores de papel e as palavras têm um corpo. É por esse motivo que não se pode simplesmente rebaixá-los a actantes narrativos: os actantes narrativos, sujeito, objeto ou destinador não possuem um corpo; são simplesmente funções, papéis abstratos ligados a predicados. Para encontrar os corpos dos actantes é preciso se posicionar, em um nível superior do discurso, sob o controle de uma enunciação em ato, organizada em torno do corpo próprio da instância de discurso" (FONTANILLE, 1999, p.70, tradução nossa). 
óticas-objeto em geral, ao lado de figuras temporais e espaciais. Dentro da dimensão figurativa, o corpo ocupa um lugar à parte, relacionado ao ator, e mais particularmente ao ator da enunciação, razão pela qual as figuras corporificadas resultam em propriedades enunciativas.

Nesse artigo, pretende-se, primeiramente, oferecer um recorte da semiótica do vestígio e, depois, observar como ela pode jogar luzes sobre uma obra literária, o romance de ficção científica Os Androides Sonham com Ovelhas elétricas?, de Philip K. Dick (1968). Adiantamos que tal recorte será feito a partir do que julgamos pertinente do ponto de vista do romance, e não reflete a totalidade das ideias do semioticista. Nossa pretensão é dupla: (a) expor alguns conceitos da abordagem, ainda pouco discutida (tentaremos fornecer alguns exemplos ilustrativos que não existem na obra original); (b) demonstrar como esses conceitos podem se ajustar ao texto literário, em uma análise que, a nosso ver, é inédita, pois tratando dos vestígios do corpo, propõe abordagens diferentes das propostas pela semiótica clássica, constituindo um novo paradigma analítico do texto narrativo.

Fontanille divide Corps et Sens em duas partes: a primeira trata do corpo do actante e do corpo sensível; e a segunda, das figuras do corpo, das figuras do vestígio e da memória. Antes de iniciarmos a análise do romance, explicitaremos alguns desses conceitos. 


\section{A - Sobre conceitos chave}

\section{0 corpo do actante: corpo-actante e corpo sensível}

Fontanille (2011, p.12-13) diferencia o "actante como corpo" e o "corpo como actante", intentando, de um lado, ir além de suas propriedades formais, semântico-lógicas, reconhecendo que seus papéis nas transformações narrativas são determinados por propriedades corporais formadas de matérias e forças; e de outro, compreender por quais processos e sob quais condições um corpo transforma-se em actante, seja ele como instância de enunciação, seja ele como actante narrativo do enunciado. Além de uma regularidade sintagmática formal, calculável a partir de predicados, procura-se entender o actante como instância corporal com carne e forma, local e vetor de impulsões e resistências que contribuem com atos transformadores dos estados de coisas que animam os percursos da ação em geral. 0 autor de Corps et Sens divide o corpo em duas instâncias básicas: o Moi, que distingue os corpos-actantes de todos os outros corpos; e o Soi, a identidade que se constrói durante o processo semiótico. Ambos são inseparáveis, "o verso e o reverso da mesma entidade" (FONTANILLE, 2011, p. 13). Assim: 
Quadro 1 - Características básicas do corpo do actante

\begin{tabular}{|c|c|}
\hline O Moi (carne) & O Soi (idem / ipse) \\
\hline $\begin{array}{l}\text { - corresponde à carne. } \\
\text { - possui constituição dupla } \\
\text { (material e energética). } \\
\text { • é o centro de referência da tomada } \\
\text { de posição semiótica elementar, } \\
\text { podendo resistir ou contribuir para } \\
\text { a ação transformadora do estado } \\
\text { de coisas. } \\
\text { - é, ao mesmo tempo, fundamento } \\
\text { da dêixis e núcleo sensório- } \\
\text { motor, pois aciona o corpo para o } \\
\text { movimento ou para o descanso, } \\
\text { para a retensão ou para a } \\
\text { protensão. } \\
\text { - é também o próprio sujeito } \\
\text { cognitivo, aquele que pensa, } \\
\text { experimenta e emite sons. } \\
\text { - para existir, precisa de uma } \\
\text { estrutura que o faça mover-se, } \\
\text { necessita chamar o corpo à ação: } \\
\text { assim envolve o Soi. } \\
\text { - é a parte do actante ao qual } \\
\text { o Soi se refere ao se construir, } \\
\text { fornecendo impulsão e resistência } \\
\text { ao Soi, que o permite vir a ser no } \\
\text { devir. } \\
\text { - é o suporte da experiência e } \\
\text { promove a expressão. }\end{array}$ & $\begin{array}{l}\text { - rege o corpo próprio. } \\
\text { - divide-se em idem (apreensão: } \\
\text { sempre o mesmo; a identidade) } \\
\text { e ipse (visada ou foco: } \\
\text { transformação; a alteridade). } \\
\text { - é a parte do actante que o Moi } \\
\text { projeta para poder se construir em } \\
\text { movimento. } \\
\text { - fornece ao Moia sua reflexividade, } \\
\text { da qual ele necessita para perceber } \\
\text { a mudança de si mesmo. O Moi } \\
\text { se move, se deforma, resiste, e } \\
\text { força o Soi a defrontar-se com } \\
\text { sua própria alteridade, problema } \\
\text { que este se esforça em resolver, } \\
\text { seja por repetição e similitude, } \\
\text { seja pela visada constante e pela } \\
\text { preservação. } \\
\text { - é o suporte da existência e } \\
\text { da elaboração de conteúdos de } \\
\text { significação. }\end{array}$ \\
\hline
\end{tabular}

Fonte: Quadro elaborado pelos autores do artigo a partir de Corps et Sens (FONTANILLE, 2011).

0 actante toma forma e identidade a partir de regras gerais de "figuração" que não devem ser confundidas com a figurativização dos atores, espaços e tempos da narrativa. As "figuras" são esquemas dinâmicos aplicáveis a entidades 
"materiais", e compõem globalmente uma morfologia e uma sintaxe figurativa. As figuras existem a partir de diferentes estados e etapas de interação entre matéria e energia, ao se converterem em formas auto-organizadas e forças de excitação e inibição. São tais formas e forças que permitem descrever a "figuração" do corpo-actante.

Os limites da forma auto-organizada (e em consequência, de atos significantes) são definidos pela resistência e pela inércia da estrutura material e energética do objeto. 0 corpo é submetido a forças que opõem dois limiares de inércia: o limiar da remanência (que exprime a resistência do sistema à inversão de forças e em que o corpo admite a transformação por acumulação) e o limiar da saturação (que exprime a capacidade de resistência do sistema à aplicação de forças e em que o corpo não admite transformação, atingindo uma resistência à variação de intensidade, o que ocasiona sua estabilidade morfológica e icônica) ${ }^{6}$. A inércia pode ser considerada como uma primeira estrutura modal que determina e permite extrair um esquema de natureza actancial a partir de um sistema físico em devir: o corpo "pode-fazer", pois é capaz de gerar a sua própria inércia, que fornece ao corpo-actante as propriedades figurais elementares: autonomia esquemática, singularidade e identidade.

A sucessão mais ou menos ritmada da aplicação de forças opostas e alternadas envolve o corpo-actante em um processo

6 Enquanto uma bexiga é soprada, ela possui uma inércia por remanência e o ar a modifica. Ao estar completamente cheia, porém, ela adquire uma inércia saturada e sua forma não pode ser mais alterada. Estando saturada ela pode ou voltar à posição original (vazia, em que o processo pode recomeçar), ou explodir (e alterar completamente de forma). Fontanille parece defender que se podemos nomear algo, é porque a matéria possui uma estabilidade formal e morfológica que vai além da pura significação simbólica. Nesse caso, a pergunta sobre algo ser ou não o mesmo (na questão de uma sequência de fotografias de uma pessoa, tiradas ao longo do tempo), apesar de só poder ser resolvida pela linguagem, trai a percepção da estabilidade de traços icônicos. 
sintagmático realizado por um sistema corporal dinâmico, dotado de capacidade de memória de interações. Essa memória pressupõe a capacidade da substância corporal de conservar o vestígio de forças, pressões e tensões que ela experimenta, e interações das quais participa. A memória corporal possibilita ao corpo a aprendizagem e a autoconstrução cumulativa. Ao gerenciar as tensões que sofre e que o animam, o corpo-actante desenvolve um campo sensório-motor que é "capaz de acolher as impressões da memória corporal, submetendo-as a uma primeira distinção fórica (euforia/disforia), que fornecerá sustentação à formação de axiologias" (FONTANILLE, 2011, p. 17). A sensório-motricidade pode ser considerada como um subsistema de controle que é capaz de aumentar ou diminuir os limites de saturação e da remanência.

0 princípio de inércia determina a autonomia da sensório-motricidade, mas a energia carnal do Moi difere das tensões que se exercem sobre o corpo-actante, na medida em que abrange tanto a intencionalidade, quanto as orientações axiológicas. É por esse motivo que a sensório-motricidade é capaz de fornecer uma orientação axiológica ao conjunto da relação sensível com o mundo, e pode configurar a experiência e o imaginário sensíveis, fornecendo-lhes esquemas dinâmicos que os tornam inteligíveis. Entende-se agora que os atos, sendo formulados como forças de remanências e saturações advindas de um actante sensório-motor que possui personalidade e singularidade próprias, existem enquanto coesão, coerência e congruência formal auto-organizadas. 
Figura 1 - Modelo da produção do ato

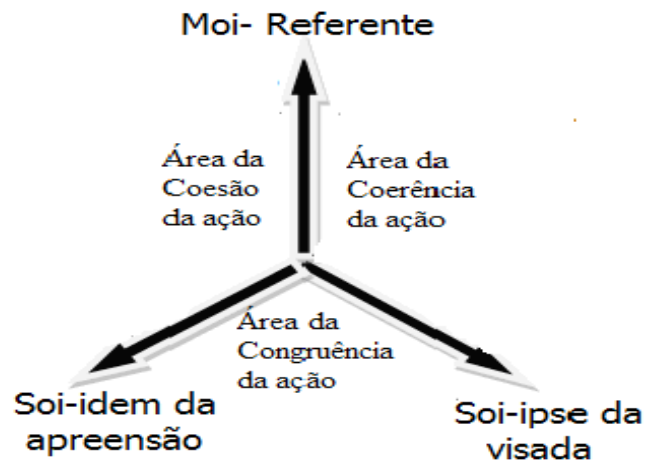

Fonte: Corps et Sens (FONTANILLE, 2011, p. 26).

Como a "dramatização da ação humana implica um corpo imperfeito, que ameaça, todo o momento, escapar do controle e do programa" (FONTANILLE, 2011, p.19), as três instâncias do actante, o Moi, o Soi-idem e o Soi-ipse, adquirem novos desenvolvimentos e relações que explicam a singularização do actante e revelam diferentes possibilidades de correlações tensivas diretas e inversas entre os três tipos de valência: formam-se zonas de valências fracas (no centro do esquema), onde, na ausência de pressões e impulsões do $M o i$ e do Soi, o ato dificilmente emerge; e zonas de valências fortes, indicadas ao redor do esquema (Figura 2): 
Figura 2 - Esquema de correlações tensivas do ato

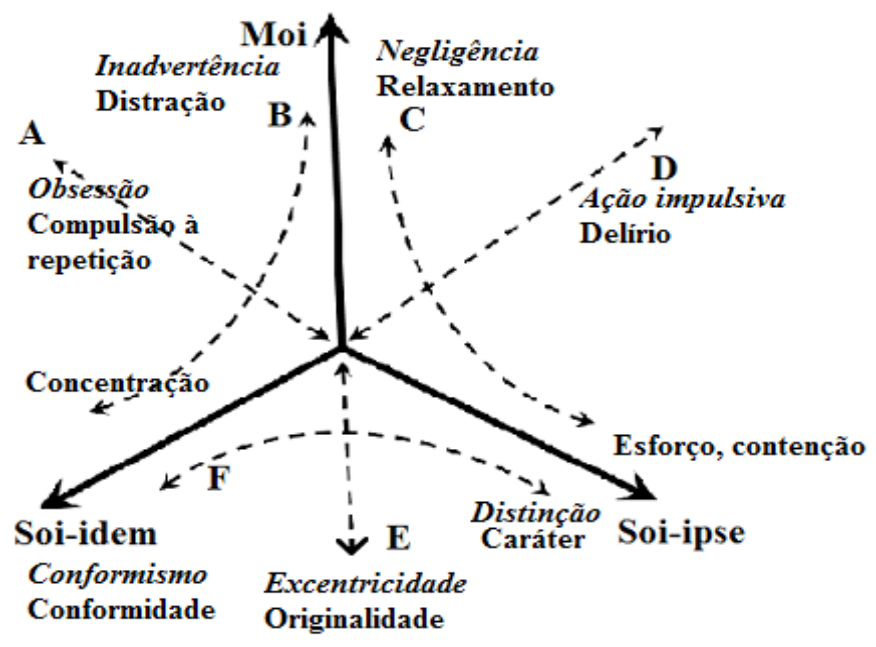

Fonte: Soma et Séma (FONTANILLE, 2004, p. 39, tradução nossa).

A tensão entre o Moi intenso e o Soi extenso também gera um modelo da produção do discurso e um conjunto de posições que relacionam duas valências responsáveis pelo estabelecimento de tipos de enunciação que incluem não apenas o discurso canônico, mas uma série de outras ocorrências discursivas: lapsos, murmúrios, acidentes vocais, repetições, clichês, etc.: 
Figura 3 - O Moi e o Soi e tipos de produções enunciativas

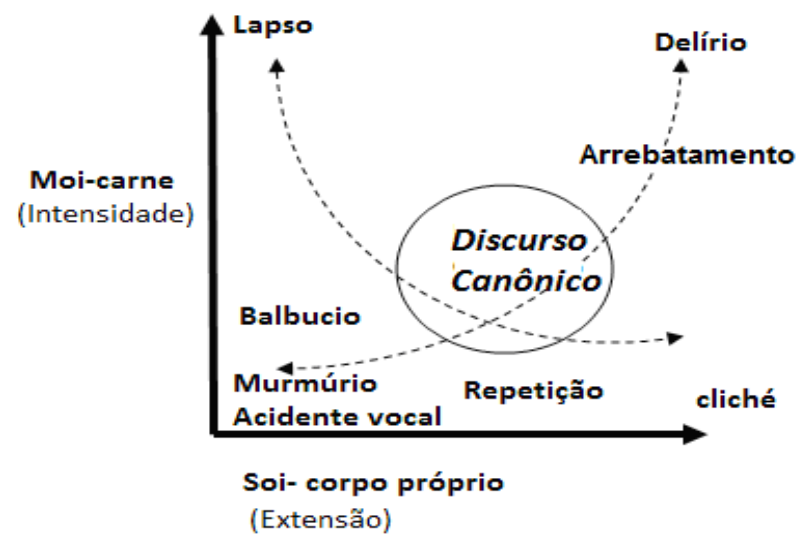

Fonte: Corps et Sens (FONTANILLE, 2011, p. 48).

O corpo e os campos do sensível

Na semiótica do vestígio, a reflexão sobre o corpo busca compreender a maneira pela qual a significação organiza conjuntos observáveis que expressam conteúdo significativo, sejam eles objetos construídos e acabados, ou práticas significantes em curso de implementação. De um lado, esses objetos podem ser simples experiências; de outro, "trata-se também de como a experiência é configurada como um objeto de sentido" (FONTANILLE, 2011, p. 53). Esse tipo de semiótica contribui para uma sintaxe figural, pois o corpo, colocado no centro da produção de sentido, fornece modelos de esquematização, de transformação e de organização de figuras. 
Os modelos perceptivos configurados pela semiótica do vestígio não devem ser confundidos com os canais sensoriais, ou seja, os cinco sentidos, e nem com os mecanismos biofísicos. A partir desse novo ponto de vista, eles são entendidos como uma contribuição do sensorial à sintaxe figural das semióticas-objeto. Assim, trata-se de explorar conjuntos de sensações capacitadas pela dimensão polissensorial da significação e da enunciação corporificada (tanto na produção como na recepção), focando a caracterização de diferentes tipos de campos sensíveis e a construção de uma tópica somática, que são capazes de descrever as diferentes figuras do corpo sensível. Essas composições sensoriais tomam a forma de campos típicos dotados de propriedades sintagmáticas específicas.

Na enunciação da percepção, os actantes transformam-se em actantes posicionais passíveis de receber uma identidade modal e de possuir sistemas de valor. Em Semiótica do Discurso (2008), Fontanille explica que esses actantes formam uma estrutura canônica elementar: podem ser distinguidos em actantes fontes (a origem da orientação), alvos (a posição visada pela orientação), e controle (que geram a interação entre a fonte e o alvo e suas modalizações) ${ }^{7}$.

0 teórico identifica e descreve oito campos sensoriais, amalgamados, mas passíveis de serem exemplificados por áreas do corpo que melhor os representam, ou onde são mais tônicos: o campo intransitivo (a própria carne ativa), o campo transitivo (o tato), o campo reflexivo (a sensório-motricidade), o campo recursivo (o odor), o campo recíproco (o olfato), o campo reversível e simultâneo (a audição), o campo sensorial interno (o paladar) e o campo debreado

7 Ver discussão em Semiótica do Discurso (2008), capítulo: “Os actantes”. 
por sobreposições ou encaixes (a visão). O princípio dessa ordenação é o da complexidade sintagmática por aplicação de novas categorias: a transitividade (e, por derivação, a reflexibilidade e a reciprocidade), a quantidade (e, por derivação, a recursividade e a sobreposição), a reversibilidade, a simultaneidade, etc. É importante observar que essa ordem não indica nenhuma hierarquia.

Paralelamente à tipologia de campos sensíveis fundados sobre suas propriedades sintagmáticas, outra tipologia mais profunda e figural emerge: a da instância corporal e a da tópica somática, que podem ser consideradas como matrizes semióticas deduzidas da tipologia dos campos sensíveis. Assim, cada campo é relacionado a uma parte do corpo-actante: o invólucro do Soi, delimitação de uma fronteira; o invólucro plural e poroso, camadas concêntricas e englobantes; o corpo interno, onde se organiza uma cena interna ao corpo, cena de uma sequência espaço-temporal e actorial; e a carne, local corporal do imediatismo e da urgência. A partir dessas instâncias, desenvolvem-se tópicas reguladas pela oposição interno x externo, ou seja, Moi-carne e o Soi-corpo próprio, ambos confrontados pelo mundo-outro: o Soi-corpo próprio; o Soi-corpo interno; o Moi-carne e o Moi-referente. 0 desenvolvimento sintagmático da tópica somática gera diferentes tipos de campos sensíveis. Entre todas as transformações possíveis, podem-se estabelecer: a multiplicação dos invólucros, que corresponde à conversão do próprio em não próprio; a relação de campos sensoriais diversos; a invasão do campo íntimo; a animação da carne e a deformação do corpo próprio.

As flutuações dos campos sensíveis afetam diretamen- 
te a capacidade do corpo de se mover e evoluir no espaço e no tempo, bem como a intensidade das dinâmicas que fundamentam esses movimentos. Adotando esse ponto de vista, a tópica somática baseia-se sobre as interações entre uma energia responsável pela animação corporal (e seus graus de intensidade), e a maneira mais ou menos estável e compreensível como as figuras do corpo se inserem e se inscrevem na extensão. A utilização de dois gradientes, um de intensidade e outro de extensão, possibilita enxergar o corpo sensível sob um novo ponto de vista, que é o das manifestações figurais. A estrutura formada a partir daí obedece a dois gráficos diferentes: o das evoluções conversas e inversas. 
Figura 4 - Manifestações figurais do corpo-actante

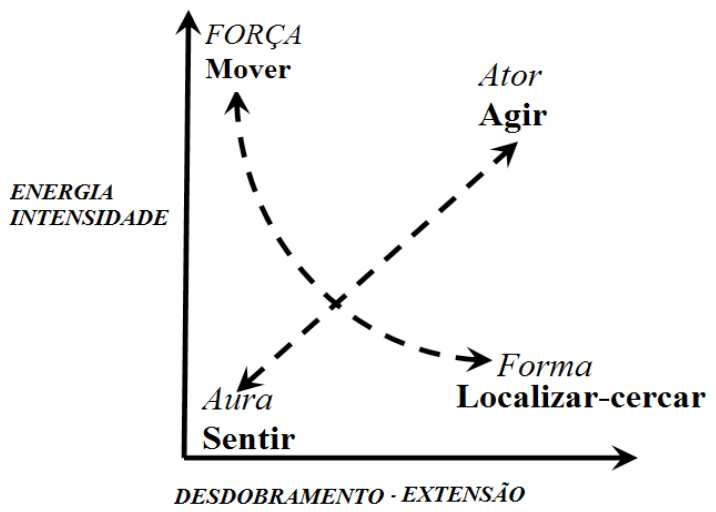

Fonte: Corps et Sens (FONTANILLE, 2011, p.77) ${ }^{8}$.

Dado um substrato material qualquer, percebido em extensão e intensidade, obtêm-se quatro tipos principais de manifestações figurais do corpo-actante; a cada uma corresponde um predicado típico, dedutível de suas propriedades sensíveis. Sob essa perspectiva, o ator não é a única figura que pode manifestar o actante, e a tipologia de actantes se enri-

8 Ator: a figura actancial conjuga uma figura de transformação e uma figura icônica identificável, o que confirma e particulariza a definição clássica do ator como o encontro entre um papel temático e um papel figurativo. Aura: o actante é percebido como uma presença sem forma identificável, e como uma eficiência sem força - uma presença mínima e potencial. Força: o actante é percebido através de seu poder de transformação, como uma presença eficiente, uma energia intensa, mas cuja capacidade de ocupação da extensão é indeterminada e não localizável. Forma: o actante é percebido enquanto ícone estável e reconhecível, com seu invólucro próprio (sua fisionomia), eventualmente marcado por inscrições específicas, que lhe conferem identidade e individualidade, mas sem nenhuma consideração por algum poder de transformação. 
quece de três formas: a força, a forma e a aura. Por isso, segundo Fontanille, a luz, o som, a massa disforme, a temperatura, etc., podem ser actantes fenomênicos discriminados, descritos como diferentes tipos de corpos presentes em um texto.

\section{As figuras do corpo, do movimento, do vestígio e da memória}

A partir das definições do corpo-actante enquanto entidade formada pela dinâmica Moi e Soi e campos sensíveis que conectam o interior ao exterior do corpo, pode-se explorar a sua manifestação figurativa, ou seja, figuras de manifestação mais frequentes, que podem ser consideradas típicas, sendo afetadas pelas interações com outros corpos e mantendo (em razão da remanência e da saturação do sistema corporal) os traços dessas interações. As figuras de manifestação carregam as impressões, as marcas e vestígios, e constituem uma memória a partir da qual isotopias figurativas são criadas ou desfeitas.

Dentro do universo das sensações, o movimento existe tanto interiormente, ao nível da carne, quanto exteriormente, ao nível do invólucro. 0 invólucro faz parte da manifestação figurativa do corpo-actante, uma vez que age como interface onde são conjugados todos os movimentos e estimulações em relação a todos os outros corpos; ele se torna a superfície de projeção de todas as interações sensíveis, internas e externas. A partir da teoria do eu-pele, postulada pelo psicólogo Didier Anzieu (moi-peau), Fontanille (2011, p. 90-92) discrimina quatro percursos figurativos típicos da pele: (a) manutenção e contenção; (b) poder distintivo e filtro de intensidade; (c) percurso de triagem axiológica; e (d) conexão e percurso de inscrição. 
As características da pele em relação à formação do ego, caras à psicologia, na semiótica do vestígio transformam-se em possibilidades figurativas do Soi-invólucro, permitindo caracterizar uma sequência em cinco fases, organizadas em: conexão > distinção e identidade > continência e manutenção $>$ troca e filtro > impressões e inscrições. A partir da figura do invólucro, é possível distinguir duas características: continência (Ct), que possui três papéis; e superfície de inscrição (SI), que opera três tipos de debreagem ${ }^{9}$ :

\section{Quadro 2 - Propriedades e operações do invólucro}

Continente (Ct)

$[\mathrm{Ct} \rightarrow\{\mathrm{Cx} ., \mathrm{Cp} ., \mathrm{R}\}$.

\begin{tabular}{|c|c|c|}
\hline Propriedades & Papéis & $\begin{array}{c}\text { Operações de } \\
\text { debreagem }\end{array}$ \\
\hline Cx - Conexidade & $\begin{array}{c}\text { Formação e } \\
\text { unificação }\end{array}$ & $\begin{array}{c}\text { Plur -Pluralização e } \\
\text { deformação }\end{array}$ \\
\hline Cp - Compacidade & $\begin{array}{c}\text { Coesão e } \\
\text { identificação } \\
\text { distintiva do } \\
\text { conteúdo }\end{array}$ & $\begin{array}{c}\text { Inv - Inversão do } \\
\text { conteúdo } \\
\text { (fora / dentro) }\end{array}$ \\
\hline R- Regulação & $\begin{array}{c}\text { Regulação de } \\
\text { trocas entre o } \\
\text { próprio e o não } \\
\text { próprio }\end{array}$ & $\begin{array}{c}\text { Proj - Projeção do } \\
\text { próprio sobre o não } \\
\text { próprio. }\end{array}$ \\
\hline
\end{tabular}

Fonte: Corps et Sens (FONTANILLE, 2011, p. 95).

9 Fontanille (2011, p. 108-110) fornece alguns exemplos de projeções e inversões fóricas: no romance $A$ Colônia Penal, de Kafka, as leis transgredidas pelos condenados são gravadas (tatuadas) em suas costas por uma máquina repleta de agulhas. A tortura, que é longa e dolorosa, possibilita ao condenado ler e entender (cognitivamente), a partir do suplício da carne, a razão de estar sendo condenado. Assim "existe uma conversão entre os vestígios do corpo invólucro e os do corpo-carne” (FONTANILLE, p.109). Da mesma maneira, a tela de cinema e a página de um texto são invólucros (SI) "grafados" por tinta e luz, que animam a carne cognitiva do espectador e do leitor. 
O invólucro, como continente do Moi, mantém a tensividade da carne; como superfície de inscrição do Soi, mantém a foria da carne:

Quadro 3 - 0 Invólucro como Continente e como SI ${ }^{10}$

\begin{tabular}{|c|c|c|}
\hline Invólucro & $\begin{array}{c}\text { Continente } \\
\text { MOI }\end{array}$ & $\begin{array}{c}\text { Superfície de } \\
\text { inscrição } \\
\text { SOI }\end{array}$ \\
\hline \multirow{2}{*}{ Carne móvel } & Tensividade & Foria \\
\hline \multirow{2}{*}{ Operações } & Conexão & Pluralização \\
\cline { 2 - 3 } & Compacidade & Inversão \\
\cline { 2 - 3 } & Regulação & Projeção \\
\hline
\end{tabular}

Fonte: Corps et Sens (FONTANILLE, 2011, p. 98).

Uma vez que carne e invólucro estão profundamente ligados, eles constituem dois paradigmas do movimento corporal. É, portanto, possível reuni-los em um mesmo sistema de valores figurativos, em que ocupam posições inversas, mas nunca dissociáveis. De um lado, tem-se a relação de contrariedade motivada pela distinção entre forma (invólucro) e matéria (carne), ou continente e conteúdo; de outro, as relações de contradição indicam um corpo-ponto, que se movimenta no espaço e possui uma referência dêitica, negando o invólucro, ou o corpo-côncavo, ou seja, a negação da matéria e da carne, onde a matéria

10 A tensividade está relacionada à incorporação do mundo natural à carne; a foria se relaciona à figuração do corpo próprio, que revela e reage a essa incorporação. 0 corpo do sujeito da enunciação é um ente tensivo-fórico. Discussão apresentada na introdução de Sémiotique des passions (GREIMAS; FONTANILLE, 1991). 
desaparece para dar vazão à agitação, causada pela cognição. Cada uma dessas figuras corresponde uma figura de movimento: deformação, moção íntima, agitação e deslocamento:

Figura 5 - Figuras do corpo e seus movimentos típicos

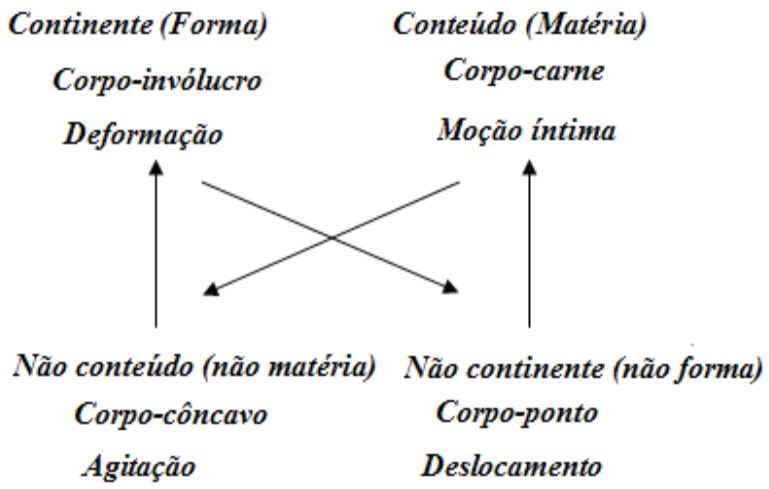

Fonte: Corps et Sens (FONTANILLE, 2011, p. $99-100)^{11}$.

- o corpo-invólucro: suporta as diversas variedades de debreagem que formam os invólucros significantes e as superfícies de inscrição. A percepção desse movimento é a percepção de deformações.

- o corpo-côncavo: fornece um espaço interior que órgãos ou atores (o paladar, ou olfato, enfim, os sentidos) podem ocupar, percorrer e modificar por seu próprio movimento; a percepção do movimento se dá como agitação interior.

11 Em Corps et Sens, os dois gráficos existem separadamente e foram reformulados pelos autores do artigo. 
- o corpo-ponto: (a posição da referência dêitica) permite perceber e apreciar o deslocamento em relação a outro corpo. Sozinho, existe como posição de referência e como base para uma mudança de posição. A percepção do movimento é a do deslocamento.

- o corpo-carne: estrutura as mudanças de consistência e de densidade, e transformações de tônus sensório-motor. A percepção de tais transformações de consistência e de densidade, independentemente de sua tradução figurativa, é sempre uma percepção de dilatações ou de contrações: os movimentos íntimos.

A relação entre as figuras do corpo e de seus movimentos motivam condições de estabilidade icônica do corpo-actante, pois sua concordância funda tanto a verossimilhança, quanto a autenticidade figurativa. A relação criada pela semiótica abre possibilidades para as mais variadas combinações, e efeitos de concordância e discordância figurativas podem ser imaginados.

Os ajustamentos sensório-motrizes e as inscrições marcadas nos invólucros se relacionam ao vestígio, que funciona por contiguidade espacial, mesmo imperfeita, e temporal; implica a interação com outro corpo ausente, que revela uma mudança de estatuto existencial - potencializado/ atualizado - e sintetiza uma sequência de interação, igualmente potencializada (a presença anterior) e atualizada (a ausência atual). Assim, o vestígio determina uma memória de interações anteriores (tanto no discurso quanto nas semióticas-objeto), cria uma sintaxe figurativa, funciona como um enunciado e gera condições de interpretação: 
- os vestígios produzidos por deformação são inscritos no corpo-invólucro, e são destinados a serem lidos e decifrados, pois ocupam uma superfície de inscrição (SI). Esse tipo de vestígio transforma o invólucro em um objeto semiótico que acolhe uma rede de manifestações plásticas tridimensionais possuidoras de propriedades físicas, tais como traço, extensão e profundidade. 0 invólucro também inclui a superfície da face e suas expressões.

- os vestígios na carne ativa podem ser vistos como encravados e resultam de marcas sensório-motoras que se originam em intensidades de emoção, dor ou esforço, de modo que não podem ser decifrados, lidos ou diretamente observados como o primeiro. Esse tipo de marca pode ser atualizado, associando uma sensação motora a um conjunto de figuras e sensações características da situação figurativa que originou aquela experiência. Esse conjunto de configurações associadas constitui um feixe sensório-motriz e tem a carne como o seu suporte, cuja elasticidade permite a aprendizagem, assim como a formação de esquemas motores a partir de contrações ou dilatações.

- os vestígios do corpo-ponto são expressos pelo movimento de deslocamento induzido por relações entre posições corporais, de modo que esse sistema de posições potencializadas, memorizadas e relacionadas à posição atual do corpo, é de natureza dêitica. 
- os vestígios do corpo-côncavo são diegéticos, cujo modo de significar será necessariamente temático e narrativo: a formação do vestígio é a apresentação de uma cena e sua interpretação é uma representação que visa à reconstituição, sob forma de enunciação de tipo narrativo, de uma cena em questão.

A operação de ancoragem da enunciação nas figuras elementares do corpo e seus vestígios são estreitamente relacionados, de modo que "a cada uma das figuras do corpo e a cada um dos tipos de vestígio associado corresponde um éthos da enunciação" (FONTANILLE, 2011, p. 117). Desse modo:

- a ancoragem dêitica garante a concordância entre duas ou várias cenas práticas e as reduz a um princípio de concomitância, sem mediação. Assim, é possível a embreagem direta de uma cena prática em outra, o que implica o princípio ético-argumentativo sob o qual uma ligação direta será mais convincente do que uma ligação indireta, sendo que aquele que a usa será mais confiável (rastros, pegadas, pistas, marcas que indicam a passagem "incontestável" de um corpo);

- o desentranhamento de marcas sensório-motoras manifesta orientações axiológicas advindas do Moi. A eficiência ético-argumentativa, nesse caso, emerge do fato de que os valores propostos são autenticados pela carne daquele que os anuncia (tremores, lapsos, gagueiras, pulsações);

- a representação de cenas obedece a um princípio 
de "presentificação", conhecido na retórica como hipotipose, a partir da qual toda a gama de sensações e emoções é explorada para engajar o campo sensorial do corpo na apreensão de uma cena. Trata-se da participação do corpo enunciativo, de modo que o corpo-actante configura um evento a partir de uma composição polissensorial, cuja complexidade e obscuridade garantem sua consciência e continuidade (imaginação, alucinação, visões);

- a decodificação ou decifração de inscrições na superfície transforma o corpo enunciativo em um texto que pode ser lido, em um suporte semiótico. 0 argumento ético se baseia na intensidade das interações anteriores e de marcas que ocorreram, de modo que, quanto mais legível, mais intensa e convincente é a causa do vestígio (podemos imaginar que atores que sofreram abusos físicos ou acidentes são geralmente figurados como corpos com vários tipos de marcas, tais como cicatrizes, depressões, desalinhamentos). 
Figura 6: A concordância entre figuras do corpo, do movimento, do vestígio e éthos enunciativo

Codificação e Decodificação

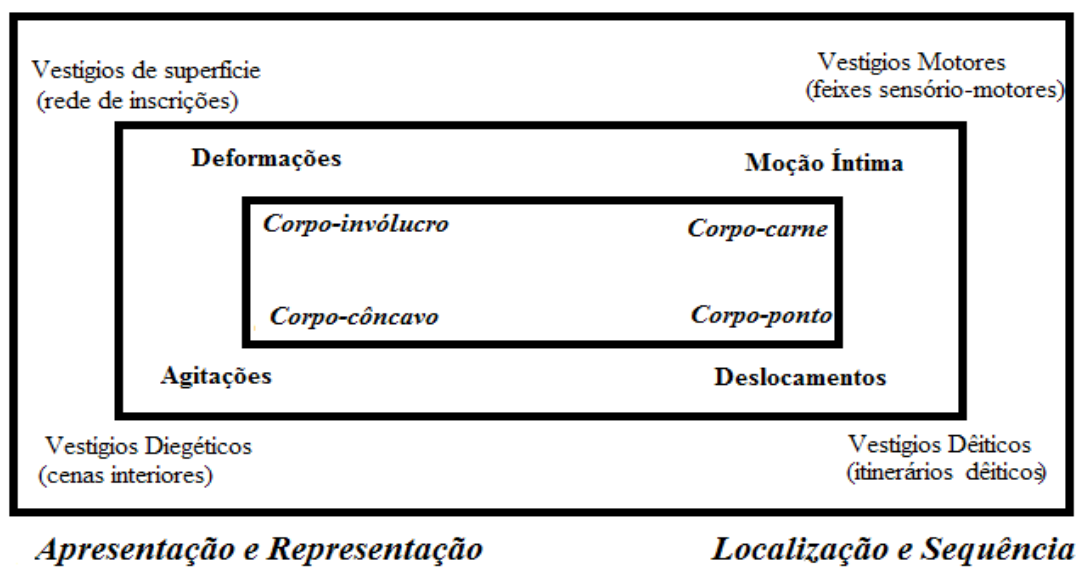

Fonte: Corps et Sens (FONTANILLE, 2011, p. 114, tradução nossa).

Logicamente, essas concordâncias e tipicidades entre corpos, movimentos, vestígios e representações podem ser embaralhadas, o que gera corpos atípicos, como geralmente acontece em romances fantásticos, de terror ou de ficção científica, onde o corpo é geralmente monstruoso, ou é manipulado e alterado pela tecnologia.

A partir desse resumo, percebe-se que semiótica do vestígio possui quatro dimensões: (a) leva em conta todas as formas de ação e enunciação, que vão além das formas canônicas e programadas, tratando da diversidade das tensões entre instâncias actanciais e seus modos de agir e falar; (b) possui proposições simples e generalizáveis que constituem uma sintaxe figurativa, tendo como princípios organizado- 
res a presença percebida, interações entre matéria e energia, sensório-motricidade, polissensorialidade e invólucro corporal; (c) sugere uma hipótese para tratar a memória figurativa do corpo-actante, que vai além da definição do actante como uma classe de argumentos de predicados, definindo como e por que as figuras do discurso conservam a memória de interações passadas, elaborando figuras de impressão e uma tipologia de interpretações; (d) abre novas perspectivas sobre o éthos do corpo-actante, graças a uma concepção encarnada do vestígio (FONTANILLE, 2011, p. 175-176). A partir dessas quatro dimensões, iniciamos a análise do romance.

\section{B - Sobre o romance Androides sonham com ovelhas elétricas? ${ }^{12}$}

\section{Resumo}

No romance de ficção científica Androides sonham com ovelhas elétricas (doravante ASOE), de, Philip K. Dick, humanos e androides lutam pela sobrevivência no planeta Terra, após a Terceira Guerra Mundial. Apesar de a guerra não ser o tema principal do livro, seus efeitos servem como pano de fundo para a narrativa, uma vez que os personagens habitam um planeta em acelerado estado de degradação por causa da radiação, tornando-se um depósito de lixo para os colonizadores que o deixaram. Toda a matéria orgânica restante no planeta está se deteriorando e se decompondo. A fauna, quase extinta, é duplicada artificialmente, e cópias de seres vivos são assimiladas culturalmente. Androides são desenvolvidos

12 Tradução de Ronaldo Bressane (DICK, 2014). 
em série, sendo continuamente aperfeiçoados e usados para diversos fins nas colônias terráqueas.

Para que não venham a substituir os humanos, androides são proibidos na Terra, sendo fabricados com duas características particulares: curto período de vida e falta de empatia. Indivíduos suspeitos podem ser testados (é comum androides, que são construídos com memórias falsas, não saberem que são artificiais). Em caso de confirmação de identidade artificial, o condenado é exterminado ou "aposentado" instantaneamente. Para identificar os seres artificiais, a polícia contrata caçadores de androides especializados, que submetem os suspeitos a um teste de empatia composto por perguntas de caráter moral e ético, que devem ser prontamente respondidas e interpretadas pelo caçador. 0 teste não computa as respostas verbais do suspeito, mas calcula as reações físicas involuntárias manifestadas em relação ao conteúdo da pergunta, revelando, por meio de sensores que medem as ondas encefálicas, a dilatação da pupila e a ruborização do rosto, e o quanto o indivíduo testado é empático.

A tecnologia faz parte integral da vida dos humanos na Terra. Além do teste de empatia, os cidadãos protegem o corpo da radiação com uma veste especial. Para evitarem a melancolia e a depressão do mundo em que vivem, as pessoas adquirem o "sintetizador de ânimo", que é um aparelho que pode controlar, a partir de um vasto cardápio de emoções, a disposição emocional do usuário. A TV é outra forma de diversão, mas não tem muitas opções: além de um canal estatal, apenas um programa é exibido: Buster Gente Fina e Seus Amigos Gente Boa, um show de variedades que é transmitido quase 24 horas por dia e é suspeito de ser uma criação androide, uma vez que é exibido quase ininterruptamente e pelas mesmas celebridades. Durante todo o romance, o programa 
promete um furo de reportagem que vai chocar os humanos e, talvez, mudar a sociedade.

Um grupo sofisticado de androides, os Nexus 6, cópias perfeitas de seres humanos, com alto grau de inteligência, foge de Marte para a Terra. Por causa da violação da lei terráquea, os androides devem ser "aposentados". Rick Deckard, o protagonista, é chamado em caráter de urgência. Sendo considerado um bom profissional, Deckard tem pouco tempo para caçar os criminosos, que se forem bem-sucedidos poderão se esconder para sempre no planeta e organizar uma resistência, fato que representaria uma ameaça à espécie humana. 0 protagonista, incumbido de localizar e "aposentar" os androides, entende que a oportunidade de trabalho é uma maneira de realizar o seu maior desejo de consumo: a aquisição de um animal real.

Antes da primeira caçada, porém, o obsoleto teste de empatia (usado nos modelos anteriores aos Nexus) precisa ser calibrado. Deckard dirige-se à Associação Rosen (a maior e mais poderosa fabricante de androides), onde deverá fazer um teste às cegas em um grupo composto por humanos e novos tipos de androides, para verificar a segurança das leituras do teste. 0 primeiro e único indivíduo testado é a sobrinha do Sr. Rosen, Rachel Rosen, uma adolescente de 18 anos que supostamente passara a infância fora da Terra, tendo pouco contato com humanos. Rachel, depois de um tenso, teste é desmascarada (e quase engana o caçador), e é o primeiro modelo Nexus 6 que Deckard encontra. 0 caçador não a mata, pois não pertence ao grupo de fugitivos, e uma vez que é propriedade particular do dono da Associação. Não apenas inteligente, mas sensual e provocante, Rachel vai abalar os valores do caçador.

O contato entre androides e humanos produz uma ten- 
são crescente entre os atores. 0 protagonista, durante a caçada, constantemente surpreso pelo grau de aparência e inteligência dos inimigos artificiais é sempre enganado e quase perde a vida várias vezes. Ao enfrentar o seu primeiro androide, Polokov, confundindo-o com um humano, o caçador demora a reagir e é quase morto. Ao tentar "aposentar" Luba Luft, uma fugitiva que prefere se esconder entre os humanos, fingindo ser uma cantora lírica, o caçador também é ludibriado e preso, sendo levado a uma delegacia "falsa" dirigida por androides. Nessa delegacia, ele encontra o seu terceiro alvo, o inspetor de polícia, outro androide disfarçado. Deckard é quase morto novamente, mas é auxiliado por Phil Resch, um caçador que não tem certeza se é humano, e desconfia que seja parte do grupo fugitivo. Phil pede para ser testado por Deckard, que promete o teste após a "aposentadoria" de Luba Luft. Depois de escaparem da delegacia falsa, os dois caçadores vão ao encontro da cantora lírica artificial e a encontram em uma exibição de Munch, onde a androide admira dois quadros do pintor expressionista. Antes de exterminá-la, Deckard se apieda dela e lhe presenteia com um livro de gravuras de Munch. A androide morre segurando duas gravuras do pintor: O Grito e Puberdade.

Deckard cumpre a promessa e testa Resch, descobrindo, para sua surpresa, que o caçador frio e violento é humano. Desconfiado de seus sentimentos, ele aplica o teste a si mesmo e percebe que sente empatia por androides fêmeas. A partir daí, moralmente confuso, o protagonista passa a refletir sobre a sua profissão, vendo-se dividido entre o dever e o lucro de exterminar as máquinas, e o desejo de poupar certas "vidas". No entanto, não desiste da caçada: ao perceber que os androides são mais ardilosos do que pensava, o protagonista pede a ajuda de Rachel. Ambos se encontram novamente em 
um hotel e fazem sexo. Deckard descobre que Rachel seduz os caçadores para que eles se apiedem de seus companheiros artificiais e pensa em exterminá-la, mas desiste.

Paralelamente à caçada, a narrativa desenvolve outra trama: a relação entre um humano em estado de degeneração e uma androide, Pris. Esta, ao fugir de Marte e alcançar a Terra, desgarra-se do grupo e se esconde no prédio de Isidore, um Especial com baixa cognição, vítima da radiação que assola o planeta, e morador solitário em um edifício abandonado. Devido ao seu estado de degeneração física e mental, ele é proibido de casar ou deixar a Terra, e sofre preconceito. Ao se encontrarem, Isidore e Pris cultivam uma pequena amizade e o Especial, que não desconfia da verdadeira identidade da companheira, sente-se mais feliz e esperançoso, prometendo fazer de tudo para ajudá-la. Horas depois, um casal junta-se a Pris no apartamento de Isidore, e a verdade sobre os desconhecidos vem à tona. Mesmo descobrindo que os desconhecidos são seres artificiais procurados pela polícia, Isidore é solidário. Como Deckard, ele passa a simpatizar com a bela androide, que é o mesmo modelo da androide Rachel, e sua sósia.

O sonho de comprar um animal verdadeiro finalmente se realiza para o protagonista. Com o dinheiro obtido pelos três primeiros fugitivos que "aposenta", Deckard consegue adquirir um animal real: uma cabra. Apesar dos vários contratempos, o resto da caçada é bem-sucedida, mas não sem surpresas. Ao voltar para casa depois de um dia exaustivo, porém, o caçador ouve da esposa que a sua cabra verdadeira recém adquirida fora morta por Rachel, que se vinga do extermínio de seus companheiros. Enlameado e desiludido, o policial, mais uma vez, reflete sobre a caçada, confessando, para sua própria surpresa, que sentira medo de ficar sem trabalho e, apesar da empatia pelos androides, não conseguira parar. 


\section{0 corpo no romance (do corpo-actante ao éthos corporal)}

Como história cujo tema é o rápido embate entre inimigos naturais e artificiais que habitam o mesmo espaço, mas são duplos (os androides podem ser vistos como moldes dos humanos), $A S O E$ é uma narrativa distópica que propõe formas de vida essencialmente tensas e tônicas, marcadas pela proximidade da presença do Outro, um espaço limitado, uma temporalidade efêmera e evanescente, e um tempo vivo e acelerado (a caçada dura aproximadamente 24 horas). A extrema semelhança entre protagonistas e antagonistas gera paixões e sentimentos que os desestabilizam como sujeitos cognitivos e pragmáticos, e seus corpos, sentimentos, percepções e ações são elementos essenciais para a diegese da narrativa, fato que gera um forte investimento na sintaxe figurativa corporal do romance. Seguindo os conceitos da semiótica do vestígio, apresentamos exemplos que justificam a nossa argumentação, observando trechos que ilustram as correlações diretas e inversas do corpo, campos sensoriais, figuras do vestígio e éthos corporal. Dividiremos a nossa análise em três partes e uma conclusão.

2.1 Moi X Soi: corpos-actantes intensos e sujeitos confusos

A cena que abre o romance é emblemática: Deckard acorda repentinamente, seu corpo é ativado por uma máquina, e surpreende-se. Já nas primeiras linhas da história, revela-se um uso bem característico do Moi do corpo-actante do personagem e do narrador observador: 
Uma curta e gostosa onda elétrica lançada pelo alarme automático do sintetizador de ânimo ao lado da cama acordou Rick Deckard. Surpreso - sempre se surpreendia ao achar-se desperto sem ter sido avisado [...] (DICK, 2014, p. 15).

O trecho problematiza a dinâmica entre sujeito e corpo, temas que serão amplificados e desenvolvidos ao longo da obra. Notam-se dois elementos na escolha semântico-discursiva do enunciado: de um lado, a reflexividade e a passividade da construção gramática (achar-se desperto); de outro, a construção de um campo perceptivo, orientado pelo actante de controle observador, que projeta dois tipos de actantes (fonte e alvo). No primeiro caso, a reflexividade aponta para a divisão entre o Moi e o Soi do corpo-actante do ator ${ }^{13}$, e seu caráter de não-sujeito, que é desperto e fica surpreso ${ }^{14}$; no segundo caso, o corpo de Deckard é o actante de uma percepção, fonte de uma visada e alvo de uma intensidade. A utilização de não-sujeitos, fontes de visadas sensíveis, afetivas e intensivas, e regidos pelo $M o i$, é comum na narrativa.

Observam-se, ao longo do romance, várias ocorrências linguísticas que saem do parâmetro do discurso canônico e revelam a intensidade de $M o i$ : Isidore, por exemplo, gagueja involuntariamente, ou fala descontroladamente, sempre que está tenso:

13 O "Eu" (no caso do romance: Ele) e o "Si" aludem ao fato exposto por Ricoeur em O si-mesmo como um outro (1991, p.11), de que as línguas possuem modos de operar e programar tipos de reflexividade (pronomes reflexivos e seus vários usos e derivações, tais como os dêiticos), que fazem com que o sujeito possa refletir sobre si mesmo, duplicar-se, ver-se como alguém que faça, sofra, planeje, ou experimente uma sensação ou ação sobre si-mesmo, de modo que o "eu" torna-se sujeito e objeto. É a partir dessa constatação que Fontanille cria a dinâmica Moi x Soi do corpo.

14 O não-sujeito é "um corpo que toma posição no campo do discurso e, por essa razão, é também o lugar das emoções e das paixões (FONTANILLE, 2008, p. 166). 
"S-SS-Senhora Pilsen?" Isidore disse, perpassado pelo pânico; ele não havia pensado nisso, claro, mas o dono tinha uma esposa que, obviamente estava em casa. - Quero fa-fa-lar com a senhora sobre o seu ga-ga-ga-ga-ga... - Interrompeu-se, coçou seu queixo involuntariamente. - Seu gato (DICK, 2014, p. 86).

O Especial também comenta que as celebridades do Programa Buster Gente Fina "nunca se repetiam [...], seus comentários sempre espirituosos, sempre novos, não eram ensaiados" (DICK, 2014, p. 80), de modo que a enunciação adquire o tom de arrebatamento. Tanto no caso da gagueira, quanto no caso do programa de TV, a enunciação adota outra diagramação textual e tem forte apelo visual e acústico, tentando mimetizar uma enunciação oral e viva:

O rádio anunciou " - ah jes wan ta tell ya, folks, that ahm sitten hih with my pal Bustuh, an we're tawkin en haven a real mighty fine time, waitin expectantly as we ah with each tick uh the clock foh what ah understan is the mos important announcement of ..." (DICK, 1968, p. 202) ${ }^{15}$.

A partir da ideia de discurso vivo, as enunciações são organizadas no romance por corpos proprioceptivos mergulhados na tensão e na sensação: de um lado, o discurso canônico é muitas vezes abandonado, e dá lugar a uma série de "acidentes vocais"; de outro, as falas, variando de tensão em relação ao Moi, ao Soi-idem e ao Soi-ipse, revelam uma perturbação na concentração, no esforço, na conformidade e na manutenção dos corpos-actantes.

15 Ah, querro contarr a voceish, psoall, quechtou sentadaqui coum meu amigo Bucherrr-, chtamouch canverrsando i nouj diverrtindou muinto, echperrandu ansiosos cada tic do relôgiou parra o que serrá o anuntsio maich imporrtant du... (tradução nossa). 
Dentro do âmbito das instâncias discursivas, devem-se acrescentar ainda ocorrências que revelam estados de consciência de atores confusos. Nesses casos, a luta pela conformidade e manutenção do crer do ator humano em relação aos androides se dá por meio de correções no uso de pronomes ou reformulações predicativas: Deckard, por exemplo, ao testar a androide, observa: "A mente dela... daquilo, estava concentrada em outros pontos" (DICK, 2014, p. 58). Ao perguntar a Rachel quantas vezes ela tinha se deitado com outros caçadores, o enunciado novamente opera uma mudança de pronomes: "Ela, ou melhor, aquilo, meneou a cabeça" (DICK, 2014, p. 191). No trecho em que Deckard entrevista um androide na falsa delegacia de polícia, o próprio narrador faz um comentário, e em seguida se corrige: "E então ele silenciou. Ou melhor, a coisa silenciou" (DICK, 2014, p. 123). A oscilação pronominal e diferentes formas de referência aos androides reflete a tensão empática causada pela semelhança entre os corpos, que interfere na própria classificação operada pela linguagem. Ao mesmo tempo, ao operar com dêiticos, a enunciação cria um efeito espacial e os remete para longe (daquilo, aquilo) do campo de presença do corpo. 0 efeito ao mesmo tempo afasta o Outro e o despersonifica.

No início do romance, após testar o aparelho Voigt-Kampff em Rachel, por exemplo, e descobrir que ela é uma sofisticada máquina, Deckard, satisfeito com a acuidade do teste, voa ao encontro de seu primeiro alvo, o perigoso Polokov. 0 encontro entre o caçador e o fugitivo é curioso, pois, ao confundir o androide com um humano, um policial soviético chamado Kadalyi, Deckard quase perde a vida. Observa-se que a confusão do caçador se dá por meio de um lapso, que é seguido de uma reformulação do erro: 
- Você não é Polokov, você é Kadalyi - disse Rick.

- Você não quer dizer o contrário? Você está um pouco confuso.

- Quer dizer, você é Polokov, o androide; você não é da polícia soviética (DICK, 2014, p. 96).

No caso de Deckard, o protagonista confunde o humano com a máquina e, apenas após ter sido corrigido, reformula o enunciado através de uma correção. A intensidade da emoção é refletida no texto, em forma de inversão da predicação, que troca os nomes próprios dos sujeitos, em um evento linguístico involuntário. Com o lapso, que ocorre no eixo da intensidade, percebe-se a rápida oscilação entre as duas identidades assumidas pelo Soi (eixo da extensidade), que interrompe a continuidade da ação do sujeito da enunciação, ameaçando a sua própria unidade. 0 lapso suspende tanto a isotopia instalada pela redundância do discurso, ou seja, o curso de sua continuação, assim como a contenção e a atenção que poderiam manter o seu novo curso, refletindo uma práxis enunciativa que oscila entre uma intenção atualizada e uma realizada.

Produzido dentro das zonas de coesão e coerência o lapso existe, de um lado, no pólo da distração, e do outro, no pólo do relaxamento. Esses dois limites estabelecem fronteiras em que o simples acidente de percurso torna-se um modo de produção de discurso perturbado, e revela um sujeito igualmente perturbado e dividido, controlado pelo Moi. 
Figura 7 - A zona do lapso

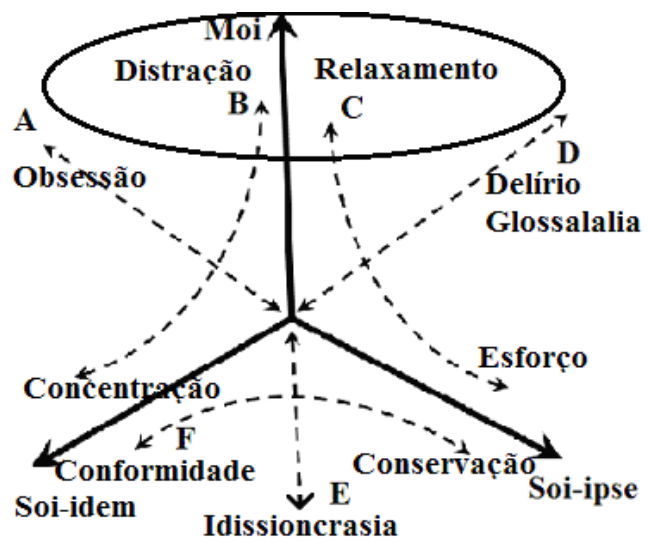

Fonte: Corps et Sens (FONTANILLE, 2011, p. 51).

Outro exemplo interessante de tensão entre o Moi e o Soi do corpo-actante do caçador é o momento em que Deckard, depois de escapar da delegacia falsa com a ajuda de outro caçador, Phil Resch, não consegue exterminar a cantora Luba Luft, uma das procuradas. É Resch que o faz. O protagonista apenas termina o serviço e o faz contrariado. Após finalizar o trabalho, Deckard sente as mãos trêmulas e pergunta a Resch se "os androides têm alma", depois anuncia ao parceiro "vou largar esse trabalho" (DICK, 2014, p.134), e confessa: "Eu não posso mais. Pra mim, chega" (DICK, 2014, p. 135). Deckard, desconfiado de suas emoções, testa a sua própria empatia e descobre que ele é diferente dos outros caçadores. 0 problema de Deckard parece advir de seu próprio corpo sensível, que não consegue controlar a empatia racionalmente. 0 narrador esclarece que:

Ele nunca tinha pensado nisso antes, nunca tinha sentido 
empatia alguma em relação aos androides que matou. Sempre admitia que, em toda a sua psique, percebia o androide como máquina inteligente bem como em sua opinião consciente. Ainda assim [...], havia se manifestado uma diferença. E ele sentiu instintivamente que estava certo. Empatia por um engenho artificial?, perguntou-se. Para com algo que apenas finge estar vivo? (DICK, 2014, p. 140).

Ao perceber que sente simpatia por certos tipos de androides, o protagonista reflete: "não há nada de antinatural ou inumano nas reações de Phil Resch; sou eu" e percebe que seus sentimentos "foram ao contrário do que deveriam ter sido" (DICK, 2014, p. 141). A descoberta de Deckard sobre os seus sentimentos em relação às máquinas femininas revela um fato inesperado em relação à sua cognição. A emoção de Deckard, porém, parece ser pontual e ainda não pode ser nomeada, aparecendo em forma de pergunta que ele faz a si mesmo, e representando um ponto de assomo. Sua emoção ainda não é sentimento e ainda não pertence a um conjunto passional determinado por uma cultura, apenas uma percepção sensível determinada por uma "sensação instintiva": mais uma percepção incerta do fazer proprioceptivo do que uma forma de racionalidade sustentanda pela lógica do discurso. Ao sentir uma emoção, e não viver um sentimento, o protagonista é um ser que busca uma nomenclatura, uma taxonomia que explique sua identidade e seus valores, os quais os outros humanos repudiam.

Deckard também não consegue "aposentar" Rachel. Após reencontrá-la para pedir ajuda e fazer sexo com ela, decide exterminá-la ao levá-la de volta para a casa. 0 caçador desiste no último momento. Ao ouvir da androide que ela seduz e se entrega sexualmente aos caçadores para convencê-los a abandonar a perseguição e sentir empatia por seres artifi- 
ciais humanoides, Deckard se enfurece, comenta que a tática é antiquada, e impulsivamente pousa o carro dizendo que vai matá-la. Ele saca o tubo de laser, mas é incapaz de prosseguir com a execução:

0 carro agora se precipitava quase próximo ao solo; ele teve de puxar para si o volante para evitar a colisão. Freando, fez com que o carro sacudisse e derrapasse antes de parar; desligou rapidamente o motor e sacou o seu tubo de laser [...].

- Não consigo fazer o que Phil Resch disse - admitiu Rick, guardando seu tubo de laser (DICK, 2014, p. 192).

O protagonista novamente, como no caso em que produz um lapso antes de exterminar Polokov, ou titubeia em exterminar Luba, manifesta uma ação incoerente com sua intenção, e o seu querer é modalizado por um não poder-fazer (impotência) e não poder-ser outro tipo de policial (impossibilidade), a partir de sensações e emoções conflitantes. No enunciado, o próprio uso da embreagem (agora) acusa o sensível; o descontrole do carro funciona como extensão de seu corpo, também descontrolado: a tensão entre idem e ipse, conformidade e esforço, pode ser observada nos dois pronomes usados no enunciado: o pronome pessoal e a sua forma oblíqua tônica (Ele/ si: uso que constatamos várias vezes no romance).

As confusões axiológicas dos atores, os seus erros, lapsos e impulsos indicam, de um lado a construção de uma sintaxe figural baseada no Moi intenso. Ao retratar o confronto entre dois tipos de seres que buscam um meio de sobrevivência, o romance propõe um choque entre sistemas de valores, que confunde a cognição e o pragmatismo dos sujeitos. Ao mesmo tempo, o enunciado constrói a tensão por meio de inúmeras reticências, que podem marcar, entre outras coisas, suspensão de pensamento ou hesitação frente ao outro. Ademais, 
podemos observar actantes que oscilam bruscamente entre o ser e o fazer, e ora possuem julgamento e têm domínio sobre os seus atos, ora agem descontroladamente. Entendemos que suas emoções de Deckard não emergem apenas de modalizações, tais como querer ou dever, mas, principalmente, de reações afetivas a presenças ${ }^{16}$. Esse novo esquema narrativo, diferente do esquema tradicional de busca, é o esquema de triagem axiológica ${ }^{17}$, como proposto por Fontanille (2011, p. 25):

\section{Mistura $\rightarrow \quad$ 2. Triagem $\rightarrow$ 3. Separação (confusão axiológica) (singularização individual) (instauração da dualidade e valor)}

No caso de Deckard, a instauração de dualidade e valor motivada por androides fêmeas, que o confundem axiologicamente, não impede que ele prossiga com seu programa. Nesse caso, o protagonista mostra ser um verdadeiro não-sujeito. Seu corpo, como o corpo do Destinador, possui uma inércia saturada, incapaz de admitir a mudança. Ao contrário dos andróides e do Especial, Deckard seria a verdadeira máquina da história, um autômato (o protagonista seria um modelo Nexus 6 com memórias implantadas?).

16 Ao explicar Coquet, Bertrand comenta: "a dimensão afetiva e passional do discurso não depende mais somente dos conteúdos modais que definem o estado do sujeito, seus estados de alma, mas leva em conta as modulações do campo de presença que esse sujeito 'sente' e o afetam" (BERTRAND, 2003, p.108).

17 Em ASOE, todos os sujeitos entram em conjunção com os seus objetos de valor, mas os perdem em seguida, de modo que suas buscas são inúteis: Deckard compra o animal real, que é morto por Rachel; o Especial faz amigos, que também são exterminados; os androides ganham sua liberdade por apenas 24 horas e são "aposentados". De certa forma, tanto o sistema de valores dos humanos (representado por Deckard e Isidore) quanto o dos androides, não são plenamente resolvidos. A dualidade de valor é suspensa pela distopia. 
2.2 Os campos sensoriais

No romance, todos os campos sensoriais do corpo são utilizados de maneira mais ou menos tônica. Ao explicarmos a dinâmica Moi x Soi, acima, percebemos a importância do uso do campo sensorial reflexivo (relacionado à sensório-motricidade, que comanda o Moi e constrói o Soi), o qual determina um tipo de uso do corpo-actante dos atores, regidos mais pela intensidade do que pela extensidade. Abaixo, comentaremos os outros campos sensoriais, que são importantes para descrever o contato entre o próprio e o não próprio dos atores em relação à percepção da presença. Como esses campos são estreitamente relacionados à carne e ao invólucro do corpo-actante, alguns dos exemplos também os levarão em conta.

- 0 campo intransitivo (relacionado à carne interna que pulsa: $\boldsymbol{o}$ Moi): esse campo é utilizado para dar apoio à figuração do corpo em dois momentos da narrativa: no teste de empatia aplicado à Rachel: "Rachel disse, distante, - minhas respostas verbais não contam. Você só vai usar como índices meus músculos oculares e a reação dos meus vasos capilares" (DICK, 2014, p. 57); e no momento que Deckard quase perde a vida, ao confundir um perigoso androide com um humano: "Sua glândula supra-renal, desacelerando vagarosamente, parou de bombear suas várias secreções em sua corrente sanguínea, seu coração voltou ao normal, sua respiração tornou-se menos frenética" (DICK, 2014, p. 97). Esse campo é importante, pois revela a tensão no corpo dos actantes, que muitas vezes não podem controlar suas emoções, amplificando a ideia de actantes alvos e não-sujeitos. 
- O campo sensorial recursivo e recíproco: no início do romance, o narrador explica que a Terra, condenada por causa da poeira radioativa, possui um odor de morte, que é farejado pelo protagonista: “O ar da manhã - transbordando partículas radioativas acinzentadas por todos os lados, encobrindo o sol - arrotava ao redor dele, infestando seu nariz; involuntariamente, farejou a contaminação da morte" (DICK, 2014, p. 20). 0 ar é personificado pela enunciação e invade o corpo do ator: como o espaço onde o caçador vive recende, esse espaço existe enquanto camadas olfativas e abrangentes, de modo que o corpo odorante do planeta é figurado como invólucro debreado que se multiplica e envolve tudo. Como corpo odorante, o ar radioativo invade o campo sensorial recíproco do ator e o não próprio é internalizado no próprio: pode-se argumentar que o corpo-actante do ator e corpo-actante do planeta partilham de um mesmo invólucro: "multiplicando os invólucros corporais difusos e porosos, o campo olfativo é local de uma conversão: a conversão dos invólucros do outro em invólucros do Soi" (FONTANILLE, 2011, p. 65).

- O campo sensorial interno: quando Isidore conhece Pris, ainda desconhecendo que ela é uma androide perigosa, ele lhe oferece um jantar modesto. Ela fica momentaneamente feliz, mas rapidamente muda de humor: intui-se, pela descrição de sua face (como superfície de inscrição) e o seu comentário, que há algo errado com sua capacidade de sentir sabor, de modo que o seu campo sensorial interno parece não exis- 
tir, incapaz de experienciar o paladar. A inexistência do campo sensorial interno dos androides abrange também sua cognição (não sabemos o que pensam) e existe em relação contrária às suas superfícies de inscrição (SI): enquanto o interior é preferido pelo narrador, o exterior é preferido pelo observador. Os androides são sempre revelados a partir do Soi corpo próprio.

- 0 campo sensorial sobreposto e o campo sensorial reversível e simultâneo: no romance, esses campos sensíveis, relacionados à visão e à audição, são extremamente importantes, pois definem a experiência perceptiva dos atores, funcionando como apoio à descrição de cenas, sendo utilizados para descreverem os androides, as alucinações frequentes de Isidore e o espaço desabitado onde vivem os atores, solitários, que é figurado como um corpo silencioso. A visão e a audição estão também presentes como temas em dois quadros de Munch, que existem como metafiguração do próprio romance e seus personagens. Por serem cruciais para a espessura perceptiva da narrativa, vamos nos deter sobre eles com mais cuidado.

O extermínio de Luba Luft é um evento extremamente importante para o caçador, pois a cantora lírica, assim como Rachel, causa uma profunda alteração em seu percurso passional. Na cena em que é morta, ela é encontrada em uma exposição de quadros de Munch, observando atentamente o quadro Puberdade, sendo depois comparada ao ser do quadro $O$ Grito. Ela é "aposentada" ao lado das duas pinturas. A men- 
ção do pintor e duas de suas obras é emblemática: em ambos os quadros, há a presença visual de um corpo sensível deformado por emoções, e essas emoções contaminam a enunciação do texto pictórico.

Tanto o romance de ficção científica quanto as obras de Munch são resultado de elaborações tímicas e fóricas apoiadas na intensidade do Moi e nos campos sensórios discutidos. Percebe-se que, nos dois, há uma debreagem do invólucro (continente) em SI, e da carne tensa em carne fórica, em operações de pluralização, inversão e projeção. Os corpos que o pintor projeta em suas telas materializam, através da expressão pictórica, estados de espírito interiores que contaminam os traços e as cores de espaços sombrios exteriores. Philip K. Dick faz o mesmo em ASOE. A caracterização corporal visual observada nas obras de Munch, assim como as observadas no romance, revela aspectos passionais dos atores androides, que sofrem emocionalmente, e que são manifestados em seus corpos-actantes: o espaço corporal interno da carne sensível deforma o Soi-corpo próprio externamente e reverbera no espaço que o cerca.

Segundo Cernuschi (2001, p.145), O Grito representa "uma tentativa calculada de recuperar um modo de expressão que funciona independentemente de sistemas codificados de linguagem". Como o enunciador, que abusa das reticências, lapsos, gagueiras e não-sujeitos, Munch questiona a linguagem e a racionalidade, adotando um estilo expressionista: linhas ondulantes, contrastes fortes de cor e massas coloridas. Przybyszewsky comenta que as pinturas de Munch "são preparações químicas da alma criadas durante o momento em que toda a razão ficou silenciosa, quando todo processo conceitual cessou de operar" (apud CERNUSCHI, 2001, p.153). 
Figura 8 - 0 Grito (Edward Munch, 1893)

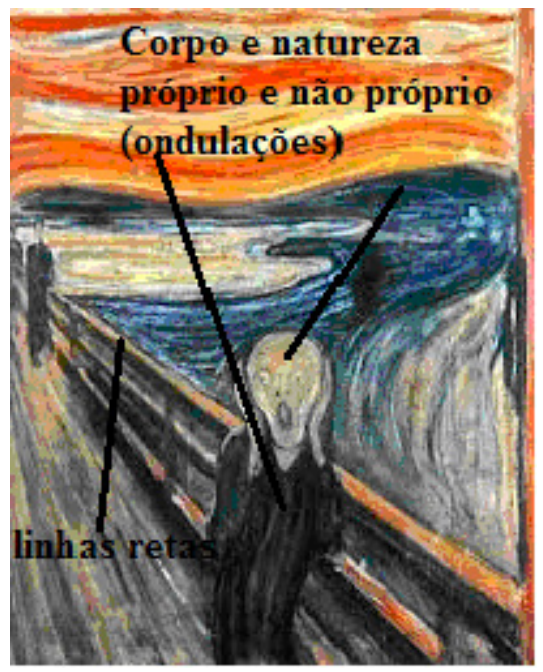

Fonte: Internet ${ }^{18}$.

Em $O$ Grito, a cabeça de uma criatura andrógina é vista com a boca escancarada e as mãos no ouvido, como se quisesse bloquear um som que não pode ser contido. Seu corpo é sinuoso e ela está em uma ponte, distanciada de dois sujeitos. 0 céu está avermelhado e tanto o corpo do sujeito quanto a natureza, atrás dele, são expressos por linhas sinuosas, em oposição ao tratamento visual que o enunciador dá à ponte $\mathrm{e}$ às duas figuras no fundo da pintura. As curvas parecem existir em uma relação semissimbólica que relaciona sujeito sensível, corpo e natureza. Nahum comenta que "uma desintegração emocional crua é projetada no ser ondulante que grita e nas linhas espirais do céu vermelho que tomam a sua forma" (2001, p. 41) e acredita que a demonstração de tais estados 
alterados indica um tipo de afeto desorganizado / desorientado. As linhas ondulantes podem também ser interpretadas como formas visuais da sonoridade. Segundo Howe (2001, p.58), O Grito "funde arte visual e som".

0 narrador observador descreve a pintura da seguinte maneira:

A obra mostrava uma criatura oprimida, sem pelos ou cabelo, com uma cabeça em forma de pera invertida, as mãos espalmadas em horror sobre as orelhas, a boca aberta em um vasto e mudo grito. Ondas contorcidas de sofrimento da criatura, ecos de seu brado, repercutiam no ar à sua volta; o homem, ou a mulher, o que quer que fosse, estava contido em seu próprio urro. Havia coberto as orelhas para não escutar o próprio som. A criatura se encontrava sobre uma ponte; a criatura gritava em isolamento. Apartada por causa ou a despeito do seu clamor [...].

- Acho... - disse Phil Resch - ... que é assim que um androide deve se sentir (DICK, 2014, p. 130).

0 trecho primeiramente descreve a criatura através da superfície de inscrição do Soi invólucro (sem pelos ou cabelo; cabeça em forma de pera); e do corpo próprio como movimento (as mãos espalmadas em horror sobre as orelhas, a boca aberta em um vasto e mudo grito), construindo o seu corpo como fonte sonora que emite camadas concêntricas de som, que enquanto a contêm, repercutem à sua volta, amalgamando próprio e não-próprio; a enunciação figura três tipos de actante: um ator, que ao mesmo tempo é forma, mas também é força, e que projeta um campo sensorial sonoro reversível e simultâneo.

Percebe-se, no romance, que o discurso não contabiliza as duas figuras na ponte, e figurativiza um corpo visto como solitário. Criatura descrita como andrógina, o ser está contido 
em seu próprio som, que forma outro invólucro que o separa de tudo (apartada por causa ou a despeito do seu clamor): uma bolha sensorial. Uma vez que o personagem do quadro não quer ouvir o som que produz, a enunciação sugere um corpo-actante incoerente: apesar do próprio e do não próprio da criatura serem expressos da mesma maneira (pelas linhas ondulantes), o seu Moi-referência (carne) e Soi-corpo próprio (invólucro) estão disjuntos (ela não quer ouvir o grito que emite de dentro, e que reverbera fora e sobre ela).

A descrição visual do corpo como deformação, e a figuração do som como corpo-actante-força, trazem à luz dois importantes elementos sensíveis na composição do romance, para o qual a pintura de Munch serve como referencial expressivo e textual: a visão do corpo como invólucro deformado a partir da carne tensa, e o som como actante- força, figurado em seus dois pólos extremos: dor e silêncio. Assim, a técnica utilizada pelo enunciador do texto pictórico coaduna-se com a utilizada pelo enunciador do texto literário.

Ao ouvir a história de Deckard na delegacia falsa, por exemplo, Phil Resch teme ser um dos androides com memória falsa que escaparam de Marte e preocupa-se: "seu rosto, agora inundado por um tormento crescente, continuava a se retorcer e a mexer em espasmos" (DICK, 2014, p.127). Da mesma forma, quando a androide Pris surge no prédio de Isidore, tentando se esconder, o enunciado, como no caso de Resch, é igualmente deformado pelo narrador observador: Pris é descrita como

uma figura encolhida, fragmentada e desalinhada [...]. 0 medo a fazia parecer doente, distorcia as linhas de seu corpo, como se alguém a tivesse quebrado e depois, maliciosamente, a reconstruído de forma maldosa. Seus olhos, enormes e vidrados, fixaram-se nele, enquanto ela tentava sorrir (DICK, 2014, p.70). 
A emoção (medo) sentida distorce a aparência de seu corpo, focalizado como SI. Assim como Resch não consegue controlar as suas expressões faciais (retorcer em espasmos, um movimento atípico para a face), Pris se esforça em sorrir (tenta). 0 verbo sugere um contra-programa passional que projeta uma tensão entre o idem e ipse do corpo-actante, e o torna idiossincrático.

0 outro quadro que se impõe como objeto metafigurativo da condição dos corpos e presenças no romance é $\mathrm{Pu}$ berdade, que possui as mesmas características temáticas e expressivas de $O$ Grito, mas parece ressaltar com mais vigor um aspecto figurativo fortemente presente no texto: o corpo feminino, a sensualidade fria e a distância. Em Puberdade, uma adolescente com o corpo delgado e seios pequenos está sentada em sua cama, solitária, tensa e com o olhar fixo. Nua e de braços cruzados sobre o torso, ela encobre o sexo. Sua sombra se projeta como outro corpo, escuro e sem forma: um volume que toma o espaço e cresce como corpo-actante força ao seu lado. Segundo Cernuschi (2001, p. 134), o quadro é "um retrato de uma adolescente passando por um período de mudança física e psicológica" e essas mudanças provocam "emoções conflitantes". 
Figura 9 - Puberdade (Edward Munch, 1894)

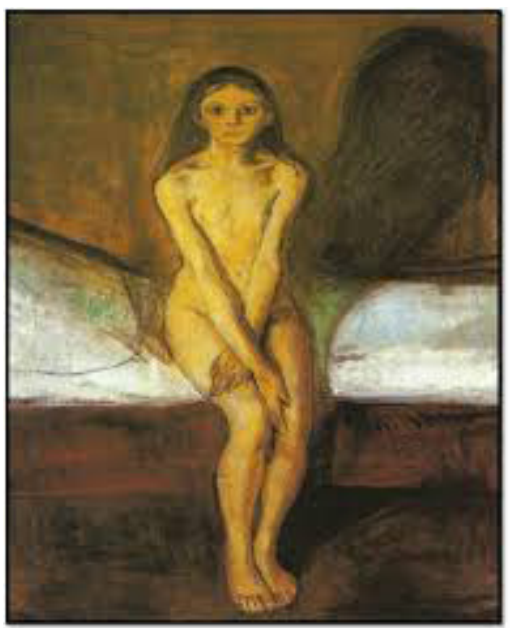

Fonte: Internet ${ }^{19}$.

A descrição de Rachel, observada por Deckard, revela uma figura parecida com a misteriosa adolescente de Munch:

As proporções de Rachel [...] eram estranhas; com o volumoso cabelo negro, sua cabeça parecia grande; e por causa dos seios diminutos, seu corpo assumia uma silhueta esguia, quase infantil. Mas seus olhos enormes, de cílios elaborados, só poderiam pertencer a uma mulher adulta; ali terminava sua semelhança com uma adolescente. [...] Sem excesso de carnes, uma barriga plana, nádegas pequenas e peitos ainda menores - Rachel havia sido modelada à compleição celta, anacrônica e atraente. Abaixo do short curto, suas pernas, esguias, tinham um caráter neutro e não sexual, não muito bem acabadas em suas deliciosas curvas. A impressão geral era boa, no entanto. Ainda que definitivamente a de uma garota, não de uma mulher. Exceto pelos olhos inquietos, ardilosos (DICK, 2014, p. 180).

19 https://www.google.com.br 
Há uma série de fatores interessantes na descrição da sensualidade de Rachel, que remetem aos quadros de Munch: o seu caráter ambíguo, que a transforma em menina e mulher, e também o corpo masculinizado ou andrógino que vimos em O Grito; Rachel, uma androide adolescente de 18 anos, é a própria encarnação da sedução pura (definitivamente uma garota) e perigosa - perigo representado pelos olhos (os mesmos olhos testados no teste de empatia, no início da narrativa). A desproporcionalidade do corpo revela uma figura conflituosa. A própria linearidade da descrição é rompida: apesar de começar pelo cabelo e descer para a cabeça, focaliza em seguidas os seios, olhos, pés, braços, barriga, nádegas, peitos. Adotando um ponto de vista oscilante, o corpo é desmembrado pelo olhar do caçador e julgado como objeto de prazer sensual.

Assim como em $O$ Grito, o som é um poderoso actante. Objetos e atores emitem sons intensos: a TV grita, a esposa do caçador tem uma voz "aguda e amarga" (DICK, 2014, p. 15), o tom de voz de Pris "é afiado como uma lâmina" (DICK, 2014, p. 144) e, quando irritada, adota uma voz que "é aguda e estentórea" (DICK, 2014, p. 160). Os atores ouvem os ruídos dos apartamentos em prédios gigantescos e abandonados: Deckard comenta que "ouve o silêncio dos apartamentos vazios" (DICK, 2014, p. 17).

Se em Munch o grito é silencioso, em Dick o silêncio é ensurdecedor, adquirindo uma força capaz de modificar o seu entorno. No início do romance, antes de encontrar a androide em seu prédio e ainda solitário, Isidore, em uma espécie de alucinação, percebe o silêncio como uma presença corporal em forma de aura, força e forma, de modo que os campos responsáveis pela audição e a visão são combinados: 
Silêncio. Cintilou a partir do madeiramento e das paredes; golpeou-o com uma potência terrível e total, como se fosse gerado por uma imensa usina. Crescia, saindo do carpete esfarrapado que cobria todo o chão. Soltava-se dos quebrados e semidestruídos utensílios de cozinha, as máquinas mortas que nunca tinham funcionado desde que Isidore havia se mudado para ali. Gotejava da inútil luminária da sala, entretecido à sua própria queda vazia e muda desde o teto salpicado de moscas. Na verdade, emergia de cada objeto dentro do campo de visão de Isidore, como se ele - o silêncio - tentasse suplantar todas as coisas tangíveis. Portanto ele assaltava não somente os ouvidos de Isidore, mas também seus olhos; enquanto o homem se fixava na TV inativa, experimentava o silêncio como se fosse visível, e em seus próprios termos, vivo. Vivo! (DICK, 2014, p. 32).

O silêncio como corpo-actante força (golpeia, cresce, solta-se, goteja, emerge) adquire estranha visibilidade (cintila), e não tem forma, limite ou consistência material, manifestando-se também como aura. Se em $O$ Grito o som é gerado por uma emoção incontrolável, sai da boca da criatura e distorce o seu entorno, em $A S O E$ o silêncio é gerado pela própria entropia, invadindo o corpo de Isidore (olhos e ouvidos), ou seja, o seu campo sensorial reversível e sobreposto, enunciados em conjunção a partir de descrição sinestésica (experimentava o silêncio como se fosse visível). Nesse caso, a sinestesia é a forma de vida perceptiva utilizada para dar conta da presença esmagadora do silêncio, e para usar essa presença como corpo-actante fonte no campo de presença intenso do corpo-actante alvo.

- O campo sensorial transitivo: apesar do forte investimento visual na sensualidade discutido acima, 
o segundo encontro entre o caçador e Rachel, que termina em uma relação sexual não descrita pelo narrador, revela uma particularidade interessante da narrativa: o uso do campo sensorial transitivo é quase inexistente na história, sendo reprimido pelo narrador. Entre o caçador e a androide há apenas um beijo, e Deckard sente os "lábios secos" (DICK, 2014, p. 181) da mulher artificial. De maneira geral, o contato tátil entre os corpos no romance é mínimo, quase inexistente. Assim, os invólucros corporais dos atores não se tocam, sendo apenas observados, de maneira que, na ausência do tato, a visão é utilizada como "tatilidade debreada", figurando a relação entre o Soi dos corpos-actantes como única forma de contato, fortemente marcado pela virtualidade, frieza e distância.

De modo geral, os campos sensoriais utilizados no romance contribuem para que os corpos sensíveis dos atores sejam figurados como corpos solitários e contidos em sensações disfóricas, corpos cujo contato tátil lhes é negado, ou cujos campos sensoriais intransitivos da carne ressoam no espaço da narrativa, como no caso dos quadros de Munch. No romance, os movimentos íntimos, associados às sensações, são figurados como centrífugos (dilatações), pressupondo um estado tensivo da carne. A carne, seja de maneira intransitiva, como no caso das palpitações internas; reflexiva, como no caso dos movimentos carnais necessários ao deslocamento; ou transitiva, nos outros casos (som e visão), é o local corporal do imediatismo e da urgência, é o local do Moi. 
2.3 Figuras do corpo, vestígio e éthos

Ao examinarmos os corpos-actantes figurados no romance, discriminamos três tipos diferentes de corpos: os corpos dos humanos são descritos em termos "carnais", pois esses tipos de corpos cometem lapsos, confundem palavras, agem de maneira inesperada e nem sempre têm controle sobre ações planejadas, revelando um corpo-carne; os corpos dos androides são descritos externamente, por deformação (linhas quebradas, falta de proporção, figura fragmentada e desalinhada), ou por marcas superficiais em seus corpos que denotam falta de empatia (o teste detecta a ruborização da face e a diminuição do tamanho da pupila), revelando um corpo invólucro; e o corpo do Especial Isidore, um ator extremamente sensível (vimos na cena em que ele tem contato com o silêncio, em seu apartamento, um forte caráter de alucinação), é descrito internamente, a partir de seu ponto de vista, o que revela um corpo-côncavo (o ator alucina várias vezes durante o romance; o mesmo supostamente acontece com Deckard, ao final da narrativa, quando ele se funde ao corpo de Mercer).

Dessa forma, no caso dos humanos, os vestígios em seus corpos são motores, no caso dos androides, são de superfície, e no caso do Especial, são, além de motores (gagueira), diegéticos ou cognitivos (alucinações). A partir da concordância das figuras do corpo, seus movimentos, vestígios e éthe, ASOE adota estratégias enunciativas de "codificação e decodificação", "encravamento e desencravamento", "apresentação e representação". Dessa maneira, temos três tipos de éthe interpretativos relacionados aos corpos dos atores: 
Figura 10 - A concordância entre o tipo de corpo, movimento, vestígio e éthos

O éthos interpretativo (androides). $\quad 0$ éthos interpretativo (humanos).

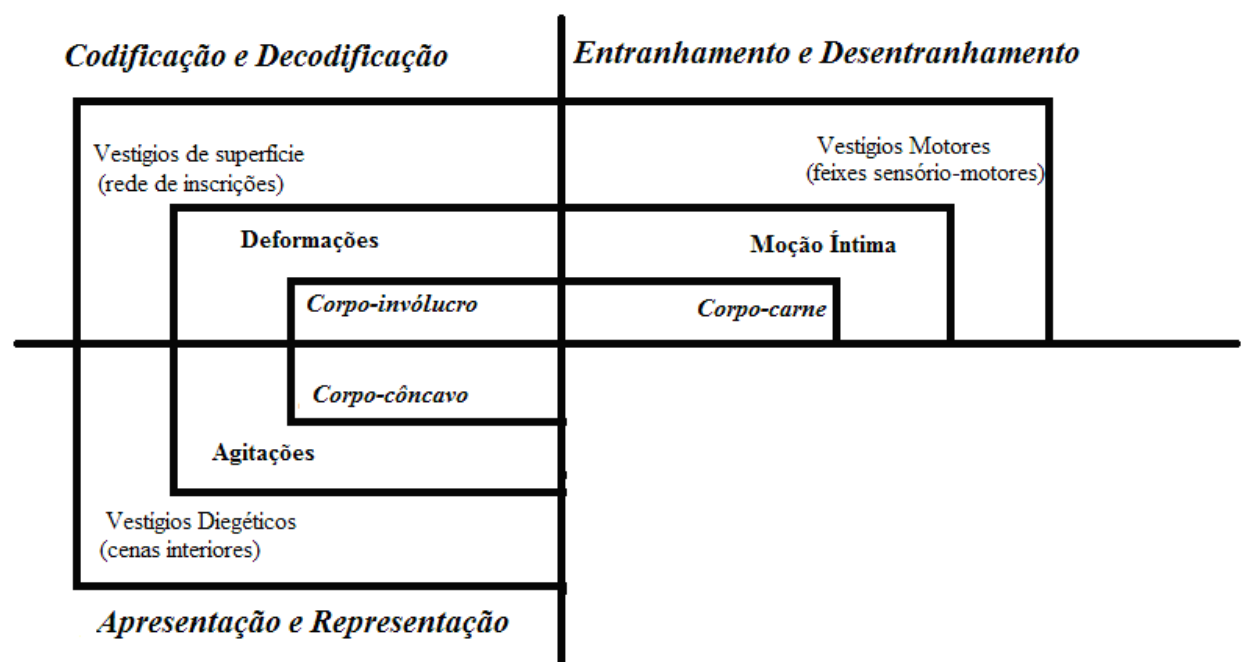

O éthos interpretativo (o Especial).

Fonte: Corps et Sens (FONTANILLE, 2011, p. 114).

Segundo Fontanille (2011, p. 117), a ancoragem da enunciação nas figuras elementares do corpo e de seus vestígios está relacionada à "héxis corporal", ou seja, a movimentos que o sujeito exerce dentro de uma prática: figuras e vestígios são relacionados a um éthos de enunciação, de modo que cada vestígio participa de um registro argumentativo, fiduciário e persuasivo específico, criando um universo patêmico próprio. Pode-se perceber, a partir daí, que a eficiência ético-argumentativa no romance é tripla: 
- no caso dos androides, os valores ético-argumentativos podem ser lidos como textos em seus corpos, que testemunham a força e a intensidade de interações anteriores: os androides são sujeitos artificiais construídos para serem escravos, sofrem perseguição e não podem ser livres. Apesar de ansiarem pela liberdade e serem construídos com paixões e memórias humanas (e talvez possuírem empatia), são tratados injustamente (não apenas pelos humanos, mas pelo próprio narrador observador) como seres vazios e sem interioridade, ou alma.

- no caso dos humanos, os valores ético-argumentativos estão autenticados em suas carnes. 0 ator corporificado existe como ser desorientado cognitiva e pragmaticamente: tanto suas ações quanto uso da linguagem oscilam, dominados por um Moi que sofre, e assimila continuamente as pressões de presenças distópicas, readaptando continuamente o Soi corpo-próprio, que não consegue se firmar como figura normal e estável, ou típica.

- no caso do Especial, os valores ético-argumentativos estão escritos em cenas interiores: Isidore, cujo corpo está em estado de degeneração, ou em estado de mutação genética, possui uma relação com a realidade distópica puramente imaginativa, delirante, polissensorial e sinestésica. Como sujeito mais sensível e mais empático do romance (protege os androides e chora quando Pris é morta pelo caçador), o personagem é utilizado pelo enunciador como mediação 
ética entre humanos (é anti-sujeito e alter ego do caçador) e androides, e como exemplo de "possibilidade de convivência e harmonia entre estranhos". Isidore, possuindo uma cognição degenerada, pensa de maneira diferente, engajando-se de maneira alucinatória à realidade que o cerca.

Finalmente, como os androides são marcados pela exterioridade, os humanos pela interioridade, e o Especial pela sensibilidade interior, e o romance explicita que todos são idênticos, poderíamos ainda fazer um exercício imaginativo e amalgamar esses corpos figurados distintamente, mas que são duplos, cópias ou sósias, em apenas um corpo (formado de "invólucro" androide, "carne" humana e "sensibilidade" mais cognitiva e empática), revelando, assim, uma interessante conjunção entre cultura e natureza, e máquina e homem. Desse ponto em diante, uma discussão sobre a importância do romance para a "imaginação" de novos tipos de corpos e indivíduos na cultura pós-moderna e pós-humana poderia ser iniciada.

Grahan (2002, p.17) sustenta que a literatura fantástica ou ficcional sobre o monstro, ao qual se filiam androides e mutantes, deve ser vista como representações de tentativas importantes de compreensão de tipos de discursos que serão os mais evocativos e representativos da cultura ocidental do século 21. 0 monstro, o fantástico e o místico são importantes referências para se determinar que tipo de versão de ser humano possa prevalecer no futuro, o que gera questões de caráter ético, moral e político, e seus desdobramentos, tais como identidade, participação social e distribuição de valores, articulando novas significações sobre o "ser" em uma era digital e biotecnológica. $A S O E$ é um romance que cria, a partir 
do corpo dos atores, diferentes ethé, instituindo figuras antagônicas que reflitam valores, deveres e obrigações para com o Outro (que podemos, por conveniências inerciais, considerar como sujeitos ou objetos).

\section{Conclusão}

A partir da semiótica do vestígio, formula-se outro tipo de aproximação da narrativa, que, não negando a semiótica greimasiana, revela características discursivas mescladas a um corpo sensível, dentro de questões da experiência semiótica, convertidas em semióticas-objeto, que se transformam em planos de imanência e que geram expressões articuladas ao conteúdo do texto.

Produzido por um enunciador corporificado, o discurso literário transforma tipos de experiências semióticas (que não devem ser confundidas com "espelhos do real") em semióticas-objeto, que abrangem signos, textos-enunciados, objetos, cenas práticas, estratégias e formas de vida, e que servirão de base expressiva para o conteúdo da narrativa. Assim, o enunciador aciona um corpo carnal tenso (um simulacro semiótico) que se posiciona dentro da ação e "debrea" sobre uma superfície de inscrição, o texto (por inversão, pluralização e projeção de seu corpo-objeto), essa tensão em conteúdos fóricos, formados de expressões formais das semióticas-objeto imanentes e do conteúdo formal da linguagem.

Em ASOE, por exemplo, percebemos o uso de verbos e pronomes reflexivos, sugerindo confusões axiológicas de identidade; reformulações de frases e enunciados, sugerindo falta de controle da sensório-motricidade e perda de controle da linguagem; uso expressivo de reticências, sugerindo inter- 
rupções no pensamento e suspensões de ideias; oscilações ou embreagens dêiticas, sugerindo dúvida em relação à identidade do outro, ou o contato sensível com o mundo, que se faz "presente" no instante do enunciado; organização tópica das palavras nos enunciados, sugerindo actantes transformacionais e posicionais, e relações intensas entre presenças (fontes e alvos); fortes quebras de isotopias textuais, que provocam problemas de coesão, coerência e congruência na narrativa, e criam tensões cognitivas sobre espaço, tempo e sujeito; assim como figurações distópicas dos mesmos, sugerindo um mundo natural e sociocultural problemático para os atores (argumenta-se que o mundo ficcional "existe" na imaginação do enunciatário, por causa das semióticas-objetos do percurso da expressão, que são sempre similares às dele, ser sociocultural, em maior ou menor grau).

Em termos de corpo, o romance explora: o $\mathrm{Moi}$, como parte do corpo-actante, mais problemática em todos os atores (humanos e androides), pois ele será o suporte da existência conturbada e dos conteúdos da significação do Soi dos corpos; o campo sensorial intransitivo, reflexivo, sobreposto (visão), e reversível (audição), sendo que o campo transitivo (o toque entre os corpos) é o menos utilizado, revelando a relação fria e distante entre os atores; e três tipos básicos de figuras corporais (o corpo-carne, o corpo-côncavo e o corpo-invólucro), seus movimentos (íntimos, agitações interiores e deformações), e vestígios (motores, diegéticos e inscritos), que produzem efeitos estéticos e éticos na narrativa, e suscitam diferentes estratégias de enunciação.

Fontanille nos mostra que o corpo, ao qual o ser humano está estreitamente ligado, e sem o qual o sentido não seria possível, é um elemento de extrema importância para a produção da significação, sendo transformado em objeto pela experiência 
semiótica e servindo como plano de imanência para a expressão e o conteúdo nas mais diferentes linguagens e narrativas.

\section{REFERÊNCIAS}

BERTRAND, D. Caminhos da semiótica literária. Tradução do Grupo CASA. São Paulo: EDUSC, 2003

CERNUSCHI, C. Sex and psyche, nature and nurture, the personal and the political: Edvard Munch and German expressionism. In: Jeffery Howe (Org.). Edvard Munch: Psyche, symbol and expression. Boston: University of Chicago Press, 2001. p. 134-167.

DICK, P. K. Do androids dream of electric sheep? New York: The Random House, Inc., 1968.

DICK, P. K. Androides sonham com ovelhas elétricas? Tradução de Ronaldo Bressane. São Paulo: Aleph, 2014.

FONTANILLE, J. Sémiotique et littérature. France. PUF, 1999.

FONTANILLE, J. Soma et Séma. Paris, France: Maisonneuve \& Larose, 2004.

FONTANILLE, J. Pratiques Sémiotiques. Paris: PUF, 2008.

FONTANILLE, J. Corps et Sens. Paris: PUF, 2011.

FONTANILLE, J. Semiótica do Discurso. Tradução de Jean Cristtus Portela. São Paulo: Contexto, 2008. 
GRAHAN, E. L. Representations of the Post/Human: Monsters, Aliens and Others in Popular Culture. New Brunswick, New Jersey: Rutgers University Press, 2002.

GREIMAS, A. J. Semântica Estrutural. Tradução de Haquira Osakabe e Izidoro Blikstein, São Paulo: Cultrix, 1973.

GREIMAS, A. J; FONTANILLE, J. Sémiotique des passions: des états de choses aux états d'âme. France: Seuil, 1991.

HOWE, J. Introduction: Munch in context. In: Jeffery Howe (Org.). Edvard Munch: Psyche, symbol and expression. Boston: University of Chicago Press, 2001. p. 11-19.

NAHUM, K. In wild embrace: attachment and loss in Edvard Munch. In: Jeffery Howe (Org.). Edvard Munch: Psyche, symbol and expression. Boston: University of Chicago Press, 2001. p. 31-47.

RICOUER, P. 0 si-mesmo como um outro. Tradução de Lucy Moreira Cesar. Campinas, SP: Papirus, 1991.

RUMBLE, V. The Scandinavian conscience: Kierkegaard, Ibsen and Munch. In: Jeffery Howe (Org.). Edvard Munch: Psyche, symbol and expression. Boston: University of Chicago Press, 2001. p.20-30.

Artigo recebido em dezembro de 2015 e aprovado em abril de 2016. 
Como citar este trabalho:

GOMES, Edison; HARKOT-DE-LA-TAILLE, Elizabeth. Vestígios do corpo em um romance de ficção científica. CASA: Cadernos de Semiótica Aplicada, São Paulo, v. 14, n. 01, p. 179-239, julho, 2016. Disponível em: <http://seer.fclar.unesp.br/casa>. Acesso em "dia/mês/ano". http://dx.doi.org/10.21709/casa. v14i1.8253. 